\title{
Trade Facilitation in Ethiopia: The Role of WTO Accession in Domestic Reform
}

\begin{abstract}
Ethiopia is one of the countries with excessive challenges in cross border trade. The high cost of doing business across borders in Ethiopia has become a major constraint. The focus of this article is trade facilitation which requires the examination of the dynamic gains associated with lowering trade transaction costs and identifying the relative importance of related trade policy reform measures in Ethiopia. In particular, the current state of the law and practice in trade facilitation and the international trading environment in Ethiopia are examined. The article focuses on customs law, border institutions, transport and logistics services and various issues related with investment and trade policy. In so doing, it attempts to examine how Ethiopia's WTO Accession and trade facilitation instruments can be streamlined with domestic reform.
\end{abstract}

Tilahun Esmael Kassahun *

\section{Key words}

Trade facilitation, customs valuation, logistic services, WTO, Ethiopia

DOI http://dx.doi.org/10.4314/mlr.v8i1.5

* PhD Candidate (International Law and Economics) Bocconi University, Milan-Italy. LL.M (Business Law) Addis Ababa University, LL.M (International Economic Law and Policy, IELPO) University of Barcelona. The author teaches at Haramaya University College of Law and is currently on study leave. He would like to give his sincere gratitude to the editorial team at Mizan Law Review and the two anonymous reviewers for their valuable comments, remarks, and suggestions. He can be reached at $<$ tilahun.kassahun[at]phd.unibocconi.it $>$.

$\begin{array}{ll}\text { Acronyms } & \\ \text { CV } & \text { Customs valuation } \\ \text { CVA } & \text { Customs Valuation Agreement } \\ \text { ERCA } & \text { Ethiopian Revenues and Customs Authority } \\ \text { EPPCF } & \text { The Ethiopian Public Private Consultative Forum } \\ \text { ESLSE } & \text { Ethiopian Shipping and Logistics Services Enterprise } \\ \text { GATS } & \text { General Agreement on Trade in Services } \\ \text { GATT } & \text { General Agreement on Tariffs and Trade } \\ \text { MTO } & \text { Multimodal transport operator } \\ \text { OECD } & \text { Organization for Economic Cooperation and Development } \\ \text { TFA } & \text { Trade Facilitation Agreement } \\ \text { UNCTAD } & \text { United Nations Conference on Trade and Development } \\ \text { UNECE } & \text { United Nations Economic Commission for Europe } \\ \text { WTO } & \text { World Trade Organization }\end{array}$




\section{Introduction}

The high cost of doing business across borders in Ethiopia is said to have become a major constraint to economic development. ${ }^{1}$ Ethiopia is one of the countries with the highest set of challenges in cross border trade. The World Bank study of trading across borders ranking puts the country at $166^{\text {th }}$ in the world. ${ }^{2}$ While, on average, sub-Saharan African customs delays are the longest in the world, the average delay is 12 days in the region compared with 7 days in Latin America; the longest delays in the region are in Ethiopia - where the average trader has to wait more than 30 days for customs to clear goods. ${ }^{3}$ Transportation delays along the Ethiopia-Djibouti transport corridor are also widespread. Numerous stages in the process of clearing and transporting commercial goods in transit from the port of Djibouti to Addis Ababa can take more than 20 days. This has contributed to the country's current $132^{\text {nd }}$ rank out of 189 nations in the World Bank doing business index.

The cost of accessing information, discrepancy and unpredictability in government policy decisions, general issues of custom which in particular includes customs valuation, and anticompetitive practices in transport, especially road and sea transport are directly related to the costs of trading in addition to the delay in time taken from the port to the inland destination, or the vice versa. The longer the time taken for import/export procedures or journey, the more expensive imports, exports and production becomes rendering Ethiopian exports less competitive.

The ability of countries to deliver goods and services on time and at the lowest possible cost is a key determinant of integration into the world economy today. ${ }^{4}$ With the expansion in the volume of trade, policies that remove nontariff barriers and expedite the movement of goods and services across borders, i.e., 'international trade facilitation', have emerged at the forefront of the trade

${ }^{1}$ Tsegaye Teklu and Endris Negus (2011), The Impact of Border Clearance Procedures on the Cost of Doing Business in Ethiopia, Private Sector Development Hub, Addis Ababa Chamber of Commerce and Sectoral Associations.

${ }^{2}$ See World Bank Trading Across Borders (2013), $<\mathrm{http}$ //www.doingbusiness.org/data/exploretopics/trading-across-borders $>$ (Last accessed April 2014).

3 The country's score on the Logistics Performance Index (LPI), which measures the extent of trade facilitation in the country, is 2.59 , on a scale of 1 to 5 , ranked to be $104^{\text {th }}$ among 160 countries. See World Bank Logistics Performance Index $<$ http://lpi.worldbank.org/international/global/2014> (Last accessed April 2014)

${ }^{4}$ Jayanta Roy and Shweta Bagai (2005) "Key Issues in Trade Facilitation, Summary of World Bank/ EU Workshops in Dhaka and Shanghai - 2004", World Bank Policy Research Working Paper 3703, (September 2005), p. 4. 
agenda. $^{5}$ As Grainger notes; "over the last few decades customs tariffs have been significantly reduced. [...] Consequently, the gap between tariff duties and transaction costs has narrowed; ... in view of such low trade tariffs, the transaction cost associated with paying duties is actually higher than the duties themselves." 6

Experience shows that trade facilitation is highly dependent on infrastructural developments. $^{7}$ However, trade facilitation is not only about the physical infrastructure for trade. ${ }^{8}$ Studies indicate now that, "only about a quarter of the [trade] delays is due to poor road or port infrastructure." "Seventy five percent is due to administrative hurdles - numerous customs procedures, tax procedures, clearances and cargo inspections - often before the containers reach the port." 10 Accordingly, while undertaking the necessary infrastructural changes to implement deep trade facilitation is still important, most other measures seem to depend on strong political will. ${ }^{11}$ Development of this political will requires a clear understanding of the needs and benefits of trade facilitation in an economy.

This seems to be one part of the trade facilitation challenges in Ethiopia which suffers from excessive border bottlenecks, lack of reform and drawbacks in private investment. ${ }^{12}$ This has affected Ethiopia's international trade relation

5 Andrew Grainger (2008), "Customs and Trade Facilitation: From Concepts to Implementation", World Customs Journal, Volume 2, Number 1, p. 17.

${ }^{6}$ Andrew Grainger (2007) “Trade Facilitation: A Review”, Working Paper:

$<$ www.tradefacilitation.co.uk> , p10 (Last accessed April 2014).

${ }^{7}$ Jean-Paul Rodrigue (2013), Transportation, Globalization and International Trade, chapter $5<$ http://people.hofstra.edu/geotrans/eng/ch5en/conc5en/ch5c2en.html $>$, (last accessed April 2014) Also see UNDP, Global Event of Landlocked Developing Countries And Transit Countries On Trade And Trade Facilitation, Trade, Trade Facilitation and Transit Transport Issues For Landlocked Developing Countries, $<$ http://www.unohrlls.org/UserFiles/File/Elle\%20Wang\%20Uploads/LLDCs\%20Publi cation.pdf $>$.

${ }^{8}$ Gary Clyde Hufbauer (2012), Trade facilitation matters!, 14 September 2012. $<$ http://www.voxeu.org/article/trade-facilitation-matters> (last accessed April 2014).

9 Simeon Djankov et al. (2006), "Trading on Time", World Bank Policy Research Working Paper 3909, p. 9.

${ }^{10}$ Ibid.

11 Dan Ciuriak (2010), "Supply And Demand Side Constraints As Barriers For Ethiopian Exports - Policy Options", Bkp Development Research \& Consulting, Trade and development discussion paper no. 02/2010, p. 12.

${ }^{12}$ A report for instance states in this regard, "Customs administration and administrative entry barriers appear to be the major NTB affecting Ethiopia's trade with COMESA member states. The NTBs reported within this area with the greatest frequency include import licensing, customs valuation and formalities, and to a lesser extent, 
and has hampered its trading across borders track record at the face of global competition for foreign direct investment. This article, inter alia, examines the extent to which reforms on import and export procedures in Ethiopia that target at reducing the cost and time needed to execute trade across border can effectively move it closer to the global economy. The focus will be on the legal, economic, political, and administrative framework, i.e. soft infrastructure, rather than on traditional infrastructural challenges.

The article is aimed at filling the information gap in Ethiopia that is important to the political impetus with the objective of carrying out a 'reality check' on ground level challenges and prospects for reform. A particular focus will be the role of trade facilitation - or lack of it - in explaining Ethiopia's trade performance, trade facilitation problems and the role of reform in this area. In doing so, this article examines whether Ethiopia's accession to the World Trade Organization (WTO) will provide strategic opportunity for the country to reinvigorate its trade facilitation reform objectives in line with international principles and standards. As indicated by the World Bank, "these standards are primarily found within WTO obligations and the Kyoto Convention. Meeting one's WTO obligations and pursuing the objectives of trade facilitation" are interrelated and this calls for "the additional trade policy efficiencies by adopting the trade facilitation agenda."13 Moreover, joining the WTO binds member countries to commitments and rules that include transparency of trade laws and regulations and progressive liberalization and modernization of international trade procedures. It will also be emphasized that joining the WTO inspires confidence in the stability, predictability, and fairness of the country's treatment of its trading and investment partners. ${ }^{14}$

The article is organized into four sections. In the first section, a brief introductory review will be made on the nature, economics and benefits of trade facilitation. The section will also highlight on the current level of trade facilitation challenges in Ethiopia. The second section identifies the main trade facilitation challenges in Ethiopia that are mostly within customs law. In particular a detailed evaluation of the customs valuation practice in Ethiopia will be made with the aim of assessing the role and impact of the WTO Customs Valuation Agreement. Section three discusses the linkages between logistics

classifications. There are also complaints pertaining to pre-shipment inspection as well as consular formalities and documentation”, Imani Development International (Ltd), (2007) "Non-Tariff Barriers (NTB): Ethiopia," Final Report, p. 1.

${ }^{13}$ Brian Rankin Staples (1998), "Trade Facilitation", p $27<$ http://www.acp-eutrade.org/library/files/Staples\%20-\%20October\%201998\%20\%20Trade\%20Facilitation.pdf> (Last accessed April 2014).

${ }^{14}$ USAID Ethiopia (2007), Ethiopia Commercial Law \& Institutional Reform And Trade Diagnostic, p. 7. 
sector reform and in particular maritime transport sector liberalization and its role for trade facilitation. To this end, brief review assessment will be made on the legislative and institutional framework of Ethiopia's maritime transport followed by an overview on Ethiopia's WTO accession negotiation and its role, if any, for maritime services reform in the country. Finally a short discussion is made on the new WTO Trade Facilitation Agreement and its implications on the state of trade facilitation in Ethiopia is presented.

\section{The Nature, Economics and Benefits of Trade Facilitation}

Traditionally, the meaning of 'trade facilitation' was delimited to border procedure facilitation to make trade procedures as efficient as possible through the simplification and harmonization of documentation, procedures and information flows. ${ }^{15}$ It referred to policies and measures aimed at easing trade costs by improving efficiency at each stage of the international trade chain. According to the WTO definition, for example, trade facilitation is the "simplification of trade procedures", understood as the "activities, practices and formalities involved in collecting, presenting, communicating and processing data required for the movement of goods in international trade". ${ }^{16}$

Various international and regional organizations define trade facilitation according to their mandate and objectives. ${ }^{17}$ As will be shown below, some define it narrowly, while others provide broad definitions. The WTO website puts it as "the simplification and harmonisation of international trade procedures... for collecting, presenting, communicating and processing data required for the movement of goods in international trade." ${ }^{\prime 18}$ A slightly different focus emerges from the Doha Declaration which, in looking forward to its broad negotiation mandates, refers to "expediting the movement, release and clearance

${ }^{15}$ Jayanta Roy and Shweta Bagai, (2005) "Key Issues in Trade Facilitation, Summary of World Bank/ EU Workshops in Dhaka and Shanghai - 2004", World Bank Policy Research Working Paper 3703, (September 2005), p. 4.

${ }^{16}$ Moïsé, E., T. Orliac and P. Minor (2011), "Trade Facilitation Indicators: The Impact on Trade Costs", OECD Trade Policy Working Papers, No. 118, OECD Publishing, $p$ 7. <http://dx.doi.org/10.1787/5kg6nk654hmr-en> (Last accessed April 2014).

${ }^{17}$ Gainmore Zanamwe, (2005) "Trade facilitation and the WTO: a critical analysis of proposals on trade facilitation and their implications for African countries", tralac Working Paper No 5/2005, p. 5.

18 WTO, Trade Facilitation, <http://gtad.wto.org/trta_subcategory.aspx?cat=33121> (last accessed June 2012). 
of goods, including goods in transit." ${ }^{19}$ UNECE defines trade facilitation as a "comprehensive and integrated approach to reducing the complexity and cost of the trade transactions process, and ensuring that all these activities can take place in an efficient, transparent, and predictable manner, based on internationally accepted norms, standards, and best practices." 20 UNECE considers trade facilitation to encompass "the systematic rationalisation of procedures and documentation for international trade." 21

The Organization for Economic Cooperation and Development (OECD) defines it as "the simplification and standardization of procedures and associated information flows required to move goods internationally from seller to buyer and to pass payment in the other direction." 22 The mission statement of $\mathrm{UN} / \mathrm{CEFACT}$ envisages trade facilitation as "the simplification and harmonisation of processes, procedures and information flows, and so contribute to the growth of global commerce." ${ }^{23}$ UNCTAD publications also pursue a broad definition. According to Poul Hansen and Liliana Annovazzi-Jakab (UNCTAD), "Trade and transport facilitation ... addresses a wide agenda in economic development and trade that may include improving transport infrastructure and services, reducing customs tariffs, and removing non-tariff trade barriers including administrative and regulatory barriers.",24

The definition of trade facilitation is constantly evolving. For example, trade facilitation issues, which can be termed as a component of trade costs, are being used differently in literature dealing with WTO issues, which again are very

19 WTO, Trade Facilitation: Negotiations The launching of negotiations on trade facilitation, <http://www.wto.org/english/tratop_e/tradfa_e/tradfa_negoti_e.htm $>$ (last accessed June 2012).

${ }^{20}$ Economic Commission For Europe (2002), Committee For Trade, Industry And Enterprise Development Sixth session, 28 and 31 May 2002 Item 20 of the provisional agenda, Trade Facilitation In A Global Trade Environment, Note by the secretariat, Distr. GENERAL TRADE/2002/21, p. 14.

${ }^{21}$ Ibid.

22 APEC-OECD (2002), Co-operative Initiative on Regulatory Reform Proceedings of the Second APEC-OECD Workshop on Regulatory Reform Merida, Mexico, April 2002: Merida, Mexico (April 2002).

23 Economic Commission For Europe, (2005) United Nations Centre for Trade Facilitation and Electronic Business (UN/CEFACT) Recommendation and Guidelines on establishing a Single Window to enhance the efficient exchange of information between trade and government, Recommendation No. 33, p. 1.

24 Poul Hansen And Liliana Annovazzi-Jakab, (2008) "Facilitating Cross-Border Movement of Goods: A Sustainable Approach", (in) The Global Enabling Trade Report (eds.), p. 67. 
narrow in a sense to deal the barriers to trade in goods and services. ${ }^{25}$ According to World Bank, "there is no standard definition of trade facilitation. In a narrow sense, trade facilitation simply addresses the logistics of moving goods through ports or more efficiently moving customs documentation associated with crossborder trade. In recent years, the definition has been broadened to include the environment in which trade transactions take place, including the transparency and professionalism of customs and regulatory environments, as well as harmonization of standards and conformance to international or regional regulations." 26

Thus, trade facilitation looks at how the procedures and controls governing the movement of goods across national borders can be improved to reduce associated costs and maximize efficiency while safeguarding legitimate regulatory objectives. ${ }^{27}$ In its narrow sense, it addresses the logistics of moving goods through ports or customs. More broadly, it encompasses several interrelated factors such as customs and border agencies, transport infrastructure, services and information technology (as it relates to better logistics), regulatory environment, product standards, technical barriers to trade etc. in order to lower cost of moving goods between destinations and across international borders. ${ }^{28}$ It is thus clear that trade facilitation cuts across a wide range of issues and sectors, from government regulations and controls, business efficiency, transportation, information and communication technology to the financial sector. Not only is it a technical issue, but also includes economic, business, administrative and policy matters. $^{29}$

This article uses the broader meaning for trade facilitation in evaluating the trade facilitation challenges, potentials and reform proposals in Ethiopia. This considers that the concept of trade facilitation has grown beyond "fixing borders" ${ }^{30}$ The reason behind those efforts that aim to address the trade

${ }^{25}$ Prabir De Cesifo (2006), "Regional Trade In Northeast Asia: Why Do Trade Costs Matter?”,Working Paper No. 1809 Category 7: Trade Policy, p 3. Presented At Cesifo Venice Summer Institute,Workshop On Understanding The Latest Wave of Regional Trade And Cooperation Agreements July 2006.

${ }^{26}$ Ibid.

27 Poul Hansen And Liliana Annovazzi-Jakab (2008), "Facilitating Cross-Border Movement of Goods: A Sustainable Approach", (in) The Global Enabling Trade Report (eds.), p. 67.

${ }^{28}$ Jayanta Roy and Shweta Bagai (2005), "Key Issues in Trade Facilitation, Summary of World Bank/ EU Workshops in Dhaka and Shanghai - 2004", World Bank Policy Research Working Paper 3703, p. 4

${ }^{29}$ Gainmore Zanamwe, supra note 17, p. 5.

30 Barbara Rippel, (2011), "Why Trade Facilitation is Important for Africa", Africa Trade Policy Notes, Note \#27, p. 2. 
challenges beyond the traditional areas is the impact on trade costs of factors along the whole trading chain. The broader meaning examines the costs that traders and producers face from production until the delivery of their goods and services to the overseas buyer and thereby includes all the transaction costs both directly and indirectly associated with the trading process. Trade facilitation measures must therefore be designed to assist countries to lower trade costs and become more competitive in regional and global markets.

Accordingly, trade facilitation is a diverse and challenging subject with benefits for both business and government at national, regional and international levels. ${ }^{31}$ It involves economic, political, business, administrative, technical and technological as well as financial issues all of which converge at easing the cost and time of trading across borders. ${ }^{32}$ Thus any measure that eases transaction and leads to time and cost reductions in the transaction cycle fits into the category of trade facilitation. ${ }^{33}$ Accordingly, the linkages between trade facilitation, trade, and development are relatively simple in theory. ${ }^{34}$ Development is enhanced through income growth, which comes from the expansion of trade, investment, and production opportunities. Trade facilitation initiatives, with the aim of lowering trade transactions costs, can enhance trade competitiveness, and expand trade flows, while at the same time playing an important role in supporting a positive business climate. ${ }^{35}$ As Krista Lucenti argues, "the benefits of improving trade facilitation include: increasing trade in goods and services; promoting competition which can spur productivity gains as well as lower prices; enhancing efficiency in both the state sector and the private sector; improving the business environment and so encouraging foreign direct

31 Chris Milner, (2005) "Trade Facilitation in Developing Countries, Centre for Research in Economic Development and International Trade", University of Nottingham, CREDIT Research Paper No. 08/05, p. 7.

32 Sarah Mellisa Ntabazi, (2010) "Combating Corruption in Customs Through Trade Facilitation: Case of East African Community", LLM Research Paper, University of Pretoria, p. 26.

${ }^{33}$ Ibid , p. 27.

${ }^{34}$ Otaviano Canuto, Facilitating Trade, Facilitating Development, Economic Monitor, $<$ http://www.economonitor.com/blog/2012/07/facilitating-trade-facilitatingdevelopment/> July 18th, 2012 Also see John S. Wilson, Policy Research Working Paper ,298 8 Trade Facilitation and Economic Development Measuring the Impact, The World Bank Development Research Group Trade.

${ }^{35}$ Matthias Helble, "Aid for Trade Facilitation", Policy Research Working Paper 5064, The World Bank Development Research Group Trade and Integration Team (2009). 
investment and increasing participation of small-and medium-sized enterprises in international trade." ${ }^{36}$

\section{Customs Valuation in Ethiopia: The Role and Impact of the WTO Customs Valuation Agreement}

Customs valuation refers to the process and method used by customs authorities to determine the value of a particular imported/exported good. Since tariffs are usually calculated as a percentage of the value of the goods (i.e., ad valorem), the particular method used to determine value will directly affect the amount of tariff duties collected on a particular import item. Due to this, customs valuation has historically been "a jealously guarded function of government with regard to international trade." 37 For many countries the discretion given to customs authorities in valuing trade for the imposition of tariffs and duties has been an important source of revenue. ${ }^{38}$ This is more so in developing countries which are often characterized by shallow tax bases. ${ }^{39}$

This is therefore of great concern to traders, as non-transparent valuation mechanisms typically combined with inefficient or even absent advance ruling mechanisms "lead to uncertainties regarding the profitability of each trade transaction." aspect of trade facilitation." 41 Various authors qualify it as "an important element in a variety of other aspects of international trade including statistics, quota and licensing arrangement, taxes and other charges levied on imports, and the application of preference systems." 42

Ethiopia has introduced several trade facilitation related measures. The proactive strategy adopted by the Ethiopian Revenues and Customs Authority

${ }^{36}$ Krista Lucenti, (2004), Is There A Case For More Multilateral Rules On Trade Facilitation? (in) Joseph E. Stiglitz (eds.) Agenda for the Development Round of Trade Negotiations in the Aftermath of Cancun, Commonwealth Secretariat, $\mathrm{p} 109$.

${ }^{37}$ FlorianA. Alburo (2006) "Customs Valuation Issues and Research Methodologies", UNDP/ESCAP ARTNeT Trade Facilitation Research Team Meeting, , Bangkok (15 March 2006), p. 3.

${ }^{38}$ Id, p. 4.

${ }^{39}$ Ibid.

40 Yann Duval (2007), "Trade Facilitation beyond the Doha Round of Negotiations", Asia-Pacific Research and Training Network on Trade Working Paper Series, No. 50, p. 9.

${ }^{41}$ Pushpa Raj Rajkarnikar (2006), "Implementation of the WTO Customs Valuation Agreement in Nepal: An Ex-ante Impact Assessment “, Asia-Pacific Research and Training Network on Trade, Working Paper Series, No. 18, $\mathrm{p} 7$.

${ }^{42}$ For instance see Walsh, T. J (2003), "Customs Valuation, Changing Customs", IMF, Washington, p. 2. 
(ERCA) has helped in introducing several policy measures which have not only streamlined the role of the customs department but has also helped the economy in a major way without compromising the collection of essential government revenue. However, various private sector surveys in Ethiopia have been able to identify that customs valuation is still an issue of particular concern. ${ }^{43}$

\subsection{The WTO Customs Valuation Agreement}

The basic purpose of the Customs Valuation Agreement, ${ }^{44}$ is to require countries to adopt a valuation system that is "fair, neutral and uniform" and to prevent the use of arbitrary or fictitious values. ${ }^{45}$ The WTO Customs Valuation Agreement is based on a "positive" as opposed to a "normative" economic principle: what the value of the goods is, rather than what the value of the goods should be, is taken as the correct customs value. ${ }^{46}$ Thus, the Agreement's primary basis of valuation is "transaction value" which is "the price actually paid or payable" by the buyer for the imported goods. If the sale was freely negotiated (and the Agreement contains rules for valuation of sales that are not), the price the buyer pays the seller can be said to best represent the actual, market value of the product, and should be used for customs purposes. ${ }^{47}$ Toward this end, the agreement requires countries to determine the customs value of 'imported'48 goods on the basis of the price paid or payable for export to the country of importation (for example, the invoice price), adjusted, where appropriate, to include certain payments made by buyers, such as cost of packaging and containers, assists (i.e. goods or services), royalties, and license fees. Buying commissions may not be included in the transaction value, discounts obtained by sole agents and concessionaires must be accepted, and no add-ins or exclusions other than those provided for in the agreement may be made to the invoice price.

${ }^{43}$ Tsegaye Teklu and Endris Negus (2011), supra note 1.

${ }^{44}$ Agreement on Implementation of Article VII of the General Agreement on Tariffs and Trade 1994 (Customs Valuation Agreement), World Trade Organization (1999), The Legal Texts, The Results of The Uruguay Round Of Multilateral Trade Negotiations, Marrakesh Agreement Establishing The World Trade Organization.

${ }^{45}$ Bernard Hoekman et al. (2002), Development, Trade, and The WTO, A Handbook, World Bank, p. 129.

46 Sheri Rosenow and Brian J. O'Shea, (2010) A Handbook on the WTO Customs Valuation Agreement Handbook of Customs Valuation, Cambridge, p 22.

${ }^{47}$ Ibid.

${ }^{48}$ It should be noted here that although the general principles expressed in GATT Article VII - which the WTO Customs Valuation Agreement implements - refer to imports and exports, the valuation methods defined in the Agreement refer only to imported goods . 
The customs authorities may reject the transaction value by following the procedures laid down in the WTO decision on shifting the burden of proof when they have doubts about the truth or accuracy of the transaction value declared by the importer. In all such cases the agreement puts limitations on the discretion of customs authorities in determining value, requiring that the value be determined by applying the following five methods, in the hierarchical (sequential) order in which they are listed: value of identical goods, value of similar goods, deductive value calculated on the basis of the unit price at which identical or similar imported goods are sold in the domestic market, less applicable deductions for costs incurred within the country of import; constructed value computed on the basis of cost of production and finally, the "fallback" method.

Except as provided in Article 4, it is only when the Customs value cannot be determined under the provisions of a particular Article that the provisions of the next Article in the sequence can be used. If the importer does not request that the order of Articles 5 and 6 be reversed, the normal order of the sequence is to be followed. If the importer does so request but it then proves impossible to determine the Customs value under the provisions of Article 6, the Customs value is to be determined under the provisions of Article 5, if it can be so determined.

The agreement also provides a list of methods that may not be used: selling price of competing domestic products, choice of the higher value when two alternative values are available, use of the selling price on the market of the exporting country or on another export market, use of production costs except if computing according to the fifth method, the price of goods for export to a country other than the country of importation, and minimum values, other arbitrary or fictitious values. The agreement requires customs authorities to accept transaction values not only in cases of "arm's-length transactions" but also in instances where transactions are between "related parties." 49 Such relationships may result, for example, from partnership, control by one company of the other, or transactions among parent companies and their subsidiaries or affiliates. In all these cases the agreement urges customs authorities not to reject customs value unless they consider that the relationship has influenced the value declared by the importer.

The Customs valuation agreement also contains several special provisions that apply to developing-country members. They have the right not to apply the agreement until five years after their accession to the WTO, (for original members, this means until January 2000), and may request an extension of this period. They are given an extra three years before they can use the fifth (computed value) method. Those developing countries which currently value

${ }^{49}$ WTO Customs Valuation Agreement, Article 1(d). 
goods on the basis of officially established minimum values can, subject to possible conditions, retain these values on a limited and transitional basis. They can reserve the right to refuse requests of importers for the fifth valuation method to be applied before the fourth, as well as other requests for using the unit value of the goods after further processing.

\subsection{Consistency of Current State of the Law and Practice with the WTO Customs Valuation Agreement}

As highlighted above customs valuation is one of the challenging bottlenecks to trade facilitation. Generally, the existing rules virtually allowed customs authorities to exercise a large amount of discretion. Accurate, reliable and timely information is costly to acquire and the rules fail to provide specific instructions when to use one valuation rule over another. The virtually multiple valuation rules regime subject businesses to uncertainty and compel importers to make deals with customs authorities to secure the most privately profitable terms for their businesses. ${ }^{50}$ Complications of this sort have compounded the situation by increasing the incentive to negotiate for the appropriate tariff and tax payments, and a favorable decision had to be reciprocated illegally. This regime and practice have spawned integrity problems in Ethiopian customs administration. In addition to the above, many business operators complain that when customs officers were dissatisfied with declared values, they frequently re-assess the value by uplifting it in accordance with administrative guidelines. No justification for increasing the import value was required other than the officer not being satisfied, and there were no adequate mechanisms for resolving valuation disputes.

Since the early 2000's, the Government of Ethiopia decided to gradually eliminate the systematic problems in the field of customs valuation (CV) via modernization of its customs practice. Yet the main observation in the context of the modernization program was the mere inclusion of valuation principles included in the WTO Customs Valuation Agreement (CVA). Recently ERCA has initiated efforts to introduce voluntary compliance of the customs and tax payers by implementing the Authorized Economic Operators program. ${ }^{51}$ These measures certainly display obvious intention of the government to initiate some genuine reforms in the field of $\mathrm{CV}$. Yet the problem still persists despite such endeavors. The first obstacle that hinders the effective operation of the CVA in Ethiopia is the absence of political will and sufficient legal framework that

${ }^{50}$ Ethiopia: Joining the WTO? (2008)The Challenge of Customs Valuation, JURIST Staffer Eric Linge, Pitt Law '10, Addis Ababa Saturday, July 05, 2008).

${ }^{51}$ Ethiopian Revenues and Customs Authority, Authorized Economic Operators (AEO), $<$ http://www.erca.gov.et/index.jsp?id=faq\& $>$ (last accessed April 2014). 
would ensure full realization of a WTO consistent valuation practice. The following sections provide several examples where the presently working rules and practices contradict the CVA provisions.

Meanwhile it should be noted that such evaluation is made for two main purposes. First, despite the fact that Ethiopia is not yet a member of the WTO, the country is well in the middle of a lengthy accession negotiation and the rules and principles of the former require Ethiopia to mainstream its national laws and practices to its rules at the time of accession, unless otherwise some exemption in terms of transition period is acquired in the negotiations. Therefore it is relevant to evaluate to what extent the current system is aligned to the expectations of the organization. Second and most importantly, it can be said that the rules and principles contained in the CVA have now become global standards. About 160 countries that are members of the WTO and two dozen countries that are either in the process of accession have adopted and largely implement rules and procedures that are provided in the CVA. In this sense we can say that implementation of the principles provided under CVA in Ethiopia is, with or without accession to the WTO, is timely and called for. It should be seen as alignment of oneself to globally harmonized rules.

\subsubsection{The Customs Proclamation}

The valuation chapter of the current Customs Proclamation contains several valuation rules which can be generally considered in line with the WTO Customs Valuation framework. Article 33 of the Customs Proclamation specifically deals with the issue of customs value of imported goods. As stated above, Article 33 (2) defines the customs value for imported goods as the actual total costs of the goods up to the first entry point to the customs territory of Ethiopia. This definition is consistent with Article 1 of CVA which stipulates transaction value of a good as a basis for customs valuation. However, despite being generally in line with the WTO customs valuation framework, the Proclamation still suffers from several consistency challengers against its WTO counterpart. First of all the currently applicable Customs Proclamation (as amended) provides under Article 32, that "the Authority shall ... prescribe other methods to be applicable in the case where the method stipulated under this Proclamation could not be applied and be applicable in the case of second-hand goods". An important compliance concern would be when the said second-hand goods are imported into Ethiopia. Under such cases an issue arises whether other methods of valuation, except for the method provided for in this Proclamation would be used to value such second-hand goods.

The WTO Customs Valuation Agreement provides for seven methods of appraisement of the goods sold for export to the country of importation and does not differentiate between new and second-hand goods. Even though it is premature to comment on how the government intends to make use of this provision, the outcome of this exception will not be compatible with the WTO 
Customs Valuation Agreement. ERCA currently uses minimum values for certain products. Second-hand goods are among the products for which minimum values are used. ${ }^{52}$ Therefore, the "other method" mentioned in Article 32, paragraph 4 of the Proclamation is the use of minimum values, and the intention of the Proclamation is to issue detailed directive on the use of minimum values. This is of course not to mention that the exception itself, as it is, is inconsistent with the WTO Customs Valuation Agreement.

The second issue relates to the fact that the Customs Proclamation does not provide for the use of the lowest value in cases where multiple identical goods or similar goods values are found. The WTO Customs Valuation Agreement is clear on how to proceed in cases where plural prices of identical or similar goods are found. Articles 2 (3) and 3(3) unequivocally provide that in such cases the lowest price should be used to determine customs value. The Ethiopian Customs Proclamation is silent on this point as are the subsequent amending Proclamations and directives. However, in practice, ERCA takes the highest of the prices that it finds. Using prices of identical or similar goods produced in another country to determine customs value is itself inconsistent with CVA. The application of the highest of multiple values practice is not consistent with CVA.

Moreover, Article 36(1) of the Customs Proclamation provides that the value "shall be determined by using the unit price of identical or similar goods imported at or about the same time and which are sold in Ethiopia in their original states in the greatest aggregate quantity to persons who are not related to the seller". This is not consistent with the WTO Customs Valuation Agreement which states that if the goods being assessed, identical or similar goods are sold in the condition as imported at or about the date of importation of the goods being appraised, the price is the unit price at which the goods being appraised, identical or similar goods are sold in the greatest aggregate quantity at or about such date. Article 5 does not refer to the use of sale of identical or similar goods in Ethiopia. A similar inconsistency can also be observed of Article 36(2) with the CVA.

\subsubsection{Ministry of Revenue Directives}

A Directive on Customs Price Database Preparation, Distribution and Utilization was issued by the now defunct Ministry of Revenue in July $2004 .{ }^{53}$ Its two main

${ }^{52}$ See detailed discussion on this below.

${ }^{53}$ Directive on Customs Price Database Preparation, Distribution and Utilization No. 10/1996, Ministry of Revenue. Before the recent BPR (Business Process Reengineering) reform the Ministry of Revenue used to be one of the three important tax and revenue administration organizations, together with the Inland Revenue Authority, Ethiopian Customs Authority and National Lottery. The reform resulted in 
objectives are stated to be combating under-invoicing through provision of up-to date price information on goods and to set up a system where similar price information is available at all customs stations. ${ }^{54}$ The first substantive element of this directive is setting up a two-tier pricing system which uses minimum prices for high risk goods and reference prices for other goods. Articles 6-10 of the directive govern the use of minimum prices. Article 6 provides that minimum prices are to be used for goods where there has been repeated underinvoicing. It identified four categories of goods namely; textiles, shoe wear, consumer electronics, and auto spare parts. For all other goods references prices are used. It is to be noted here that this system of minimum prices is inconsistent with Article 7(2) (f) of CVA which specifically prohibits determination of customs value on the basis of minimum customs values. This would mean that the ERCA has to abandon using minimum values if it is to implement the WTO CVA. However deserting the current system automatically could have severe revenue collection consequences on the country. ${ }^{55}$ This process thus has to be coordinated with bringing about an enabling environment where importers declare the correct transaction value of imported goods. ${ }^{56}$

Further area of incompatibility is with regard to the valuation methods and hierarchy order under the CVA. This is seen under Article 9 of this directive which provides that the price of an identical or similar good produced in another country shall be used where the price of that good is not brought into list under the minimum prices database. According to the WTO CVA where customs value cannot be determined using the invoice price, the price of identical goods and the price of similar goods is to be applied sequentially. ${ }^{57}$ Article 9 of this directive evidently contradicts its WTO counterpart by providing that the price of identical or similar goods produced in another country can be used for customs valuation purpose.

Another important directive is the Ministry of Revenue Directive on Used Vehicles and Goods - No.6/1996. This directive was also issued by the former Ministry of Revenue and amended by ERCA's directive on Imported Goods

overhaul of the Ministry and the two tax authorities into the Ethiopian Revenues and Customs Authority now supervised by the Ministry of Finance while the National Lottery Administration was made accountable to the Ethiopian Revenue and Customs Authority, by Proclamation No.256/2001.

54 Evgeny Polyakov and Wendwesson Shewarega (2006), WTO Customs Valuation Agreement: Impact Assessment Study for Ethiopia, Ministry of Trade and Industry, Ethiopia, Institutional Support to Trade Integration and Implementation of the IF Plan of Action in Ethiopia Project, Addis Ababa, Ethiopia , p. 21.

${ }_{56}^{55} \mathrm{Id}, \mathrm{p} .22$.

${ }_{57}^{56}$ Ibid.

${ }^{57}$ WTO Customs Valuation Agreement, Articles 2 and 3. 
Customs Duty and Tax Value Price Tariff: directive number 94/2006, with the objective of making the valuation system of used vehicles and goods transparent, equitable and accountable. The directive implemented a valuation mechanism for used vehicles and goods that is not applicable on other goods. It generally provides that the value of used vehicles and goods is to be based on the C.I.F. price of the good when it was bought sold as a new good. Based on this price, a depreciation allowance of $10 \%$ is subtracted each year with a maximum allowance for three consecutive years. This valuation method does not conform to the methods listed in the WTO valuation Agreement.

\subsubsection{Ethiopian Revenue and Customs Authority Directive}

ERCA still makes use of a directive, apparently given a confusing name; Ethiopian Customs Authority Implementation Directive to implement the Directive on "customs price database preparation, distribution and utilization directive" No. 2/1996 (E.C.), issued by its predecessor (the former ECuA) with the objective of implementing Directive No. 10/1996. The directive, 2/1996, embodies new principles which contradict with provisions in the working Customs Proclamation 622/2009.

Primarily Article 3(2) of the directive provides for one additional test to be applied sequentially to determine identical good. It provides that identical goods include goods produced by a different producer but in the same country. Where no value is found using this method it provides that goods produced in another "country with similar level of development" can be used. The additional method of using a different producer in the same country is actually in line with CVA; however the second supplementary assessment of using products of other states is inconsistent with Article 15 of the WTO valuation agreement which clearly prohibits consideration of goods produced in different countries as identical goods. ${ }^{58}$ Article 3 (4) of the directive establishes four sets of groups of countries which are considered to be in like economic development conditions. These groups are (1) European states including United States, Canada, Australia, Japan; (2) all countries in Asia except Japan; (3) countries in Latin American; and (4) all countries in Africa. ${ }^{59}$ This system is not in line with the WTO Customs Valuation Agreement. It presupposes the same production and sale value for countries in one group simply because they have comparable levels of economic development. This is a simplistic basis to establish customs value of goods.

${ }^{58}$ Evgeny Polyakov and Wendwesson Shewarega, supra note 54.

${ }^{59}$ Ibid. 


\subsection{Analysis of the Impact and Role of WTO CVA for Trade Facilitation in Ethiopia}

As illustrated in the above sections, the purpose of the Customs Valuation Agreement, as treaty among signatory countries, is to provide reciprocity between nations when they impose import duties. By using the same valuation methods in every signatory country, countries avoid the problem of using valuation as a tool for trade wars. Moreover, businesses can predict their cost of doing business in another country. Using the same valuation methods, each country then applies its own ad valorem import duty to the product. This enhances the predictability of the cost of transactions, thereby encouraging international trade. ${ }^{60}$

Today the majority of countries in the WTO share the common view that the introduction of the CVA provisions in their national customs law will play a significant positive role in the liberalization of their economies. Therefore, the reason why a number of countries choose to carry out these measures unilaterally before they join the WTO is understandable. Nevertheless, when it concerns the implementation of the WTO-CVA, many countries have incessantly confronted a number of problems that prevented the universal incorporation of the CVA provisions in their national laws. Even if most of these countries are developing countries like Ethiopia, they eventually can manage to adopt WTO-CVA amenable provisions. Today such countries have come to realize that applying the CVA means a lot more than simple introduction of the CVA articles in their national laws. ${ }^{61}$

Consequently this translates to addressing the trade facilitation needs of commerce and business in Ethiopia. Generally, the direct positive effect of switching to valuation based on CVA is the creation of a fair, uniform, and neutral system for the valuation of goods for customs purposes, that conforms to commercial realities and that prohibits the use of arbitrary or fictitious customs values, where all importers and producers are on the same level playing field. Accompanying reforms will lead to an improved trade environment, better compliance, and trade facilitation (with reduction in transaction costs). ${ }^{62}$

${ }^{60}$ David Laro and Shannon P. Pratt (2005), Business Valuation and Taxes; Procedure, Law, and Perspective, John Wiley \& Sons, Inc, p. 147.

61 Azizjon Nazarov (2007), Contemporary Implementation Problems of the WTO Agreement On Customs Valuation Into Domestic Legislation: What Can The Experience Of Some WTO Members Teach Uzbekistan?, World Trade Institute, Master Thesis), p. 51.

${ }^{62}$ For example, the WTO Committee on Customs Valuation acknowledged strong link of implementation of this Agreement with trade facilitation. See Nirmal Sengupta \& Moana Bhagabati, (2003) A Study of Trade Facilitation Measures From WTO Perspective, Revised Interim Report, Madras Institute of Development Studies, p. 7. 
Changanaqui and Messerlin (in a study on minimum import prices), show the need to consider other perverse economic effects. The findings reveal that, in addition to the farness argument raised above, minimum import prices reduce price differentials between high-priced and low-priced imported goods falling within the same product category. ${ }^{63}$ Consequently, adverse quality effects result, as there is an incentive for domestic producers to concentrate on the manufacture of low-quality goods, and an inducement for foreign suppliers to shift exports toward higher quality products. ${ }^{64}$

In the mean time, the basic implication of the Agreement in terms of trade facilitation objectives is to protect the interests of traders by requiring that Customs should accept, for determining dutiable value, the price actually paid by the importer in a particular transaction. This applies to both arms-length and related-party transactions. The Agreement recognizes that the prices obtained by different importers for the same products may vary. The mere fact that the price obtained by a particular importer is lower than other importers have imported the product, cannot be used as a ground for rejecting the transaction value. Customs can reject the transaction value in such situations only if it has reasons to doubt the truth or accuracy of the declared price of the imported goods. Even in such cases, it has to give importers an opportunity to justify their price and if this justification is not accepted, to give them in writing the reasons for rejecting the transaction value and for determining the dutiable value by using other methods. Furthermore, by providing importers the right to be consulted throughout all stages of the determination of value, the Agreement ensures that the discretion available to Customs for scrutinizing declared value is used objectively.

However, implementation of the WTO Customs Valuation Agreement should not be taken for granted in terms addressing all the trade facilitation needs of the country. It should also be noted that implementation of the WTO disciplines comes up with various capacity needs. In this regard Finger and Schuler rightly remarked that customs valuation is only an inch in the whole yard of customs operations. ${ }^{65}$ Indeed, implementation of the customs valuation agreement cannot be done in isolation without undertaking extensive reforms and without putting in place institutional safeguards to prevent misuse of the liberal valuation methods under the agreement since its provisions mostly rely on transparency in

${ }^{63}$ Federico Changanaqui and Patrick Messerlin, (19992), The Economic Effects of Minimum Import Prices (With an Application to Uruguay)," Policy Research, Trade Policy Country Economics Department The World Bank, p. 2.

${ }^{64} \mathrm{Id}, \mathrm{p} . \mathrm{i}$.

${ }^{65}$ J. Michael Finger and Philip Schuler, "Implementation of Uruguay Round Commitments: The Development Challenge", p. 7.

$<$ http://policydialogue.org/files/publications/Uruguay_Round_Finger_Schulerpdf.pdf $>$ 
trade transactions. Moreover, as the abovementioned scholars have pointed out, "while implementing tariff changes may require "no more than the stroke of a Minister's or a legislature's pen", implementation of reforms in trade procedures and trade regulations require "purchase of equipment, training of people and establishment of systems of checks and balances", ${ }^{66}$ which involve substantial expenditure. In brief, a simple look at the experience of many other developing member countries to the WTO demonstrates that an effective implementation of the Customs Valuation Agreement needs to be comprehensive, adequate and continuous. The ultimate outcome should be de jure as well as de facto compliance with all WTO CV rules in a country. ${ }^{67}$

The common concerns shared by the majority of developing countries such as Ethiopia regarding possible negative impact of the implementation of the WTO Customs Valuation Agreement relates to the possible reduction in customs revenues due to under-invoicing and lowered protection levels for domestic producers. This is an important concern as customs revenue still represents a significant share in its contribution to the national treasury combined with prevalent under-invoiced importation practices by the business community. In this sense under-invoicing of imported goods is an extremely serious and complex problem that negatively impacts on Ethiopia's economy in several ways. It means that the duties and taxes escape the tax net thereby resulting in gross economic distortions. This also leads to an uneven playing field, unfair competition and is disadvantageous to goods manufactured in Ethiopia. The challenges in under-invoicing are indeed issues of concern because there is no major decline in the instances of under invoicing even if there is a general decline in the customs duties in the last two decades.

In the mean time various strategies could be designed to address the problems of directing the country's custom valuation practice to that mandated by the WTO. Perhaps the first strategy should be a comprehensive movement towards narrowing the problem. i.e. the private sector has raised the point that under-invoicing is done only in the 50-60 percent of total transactions. It is important that those firms or sectors are identified so that all do not face the same treatment. One idea is to distinguish manufacturing and trading firms separately. In this context, there may be some choice between pre-clearance control and post-clearance control. It can be suggested that the manufacturing units may find it easier to deal with post clearance audit. In the case of the traders pre-clearance control should be made more preferred choice. The recent

${ }^{66} \mathrm{Id}, \mathrm{p} .3$.

67 Azizjon Nazarov (2007), Contemporary Implementation Problems of the WTO Agreement On Customs Valuation Into Domestic Legislation: What Can The Experience Of Some WTO Members Teach Uzbekistan?, World Trade Institute, Master Thesis, p 51. 
introduction of risk management system at ERCA can be seen as an important step in this direction.

Another important issue of concern in this line also includes the fear of consequent reduction in government revenue as Ethiopia makes a transition toward strict adherence to the valuation stages under the WTO Customs Valuation Agreement. Apparently, a review of the valuation practice dictated by various directives issued by the Ministry of Finance and Economic Development, the Ethiopian Revenues and Customs Authority etc. all have a tendency to increase the transaction value of imported goods. This has presumably inflated the transaction value consequently leading to higher taxable prices. It is from this perspective that Ethiopia would be concerned not to lose a large share of its revenue as it moves to dispel its current valuation law and move towards the more disciplined and deeply regulated valuation hierarchy. The right solution to this of course lies on the principle of aligning all trade policy instruments. The most efficient and transparent way of addressing this challenge is shifting the trade protection and revenue raising role of customs valuation to actual tariffs thus avoiding dead weight loss to the overall economy.

\section{Logistics Services Sector Reform and Liberalization: What Role for Trade Facilitation}

"the monopoly of the Ethiopian Shipping Lines on the transport of seaborne imports in effect constituted an indirect tax". 68

Logistics services which include activities required for the transportation, storage and handling of production inputs and finished products from producer to consumer (or intermediary producer), play a critical role in international trade. Consumers of logistics services are typically suppliers of products themselves. ${ }^{69}$ Consequently, the efficient supply of logistics services helps to facilitate international trade in a whole range of other products. ${ }^{70}$ The more timely, reliable and efficient the logistics supply chain, the more efficiently and reliably goods can be delivered from the point of production to the point of

${ }^{68}$ UNCTAD (2004), Investment Guide to Ethiopia; Opportunities and Conditions, UNCTAD/ITE/IIA/2004/2, p 64.

69 Institute for International Trade University of Adelade (2006) "The Relationship between Trade Liberalizatoin in the Logistics Sector and Trade Facilitation", Asia Pacific Trade and Investment Review, Vol 2, No 2, p 29, Geneally see Swedish National Board of Trade (2012) Everybody is in Services - The Impact of Servicification in Manufacturing on Trade and Trade Policy, Swedish National Board of Trade-Kommerskollegium.

${ }^{70}$ Prabir De and Amrita Saha (2013), "Logistics, Trade and Production Networks: An Empirical Investigation”, RIS Discussion Papers, Discussion Paper \# 181, p. 1. 
consumption. $^{71}$ In particular, increased international trade in unfinished products, i.e. the movement of intermediate goods within production processes, requires logistics services of ever higher quality with regard to the reliability, safety, security and frequency of deliveries. ${ }^{72}$

Accordingly, competitive advantage in both international and regional trade is increasingly defined by logistics as other factors decline in importance. ${ }^{73}$ The capacity to produce consumer goods, other than those protected by patents, can be replicated in most countries. Low labour cost is a common feature of developing countries and represents a decreasing portion of delivered cost. Tax benefits have become a standard offering with relatively little difference between countries. The traditional advantage of proximity to raw materials has increasingly been replaced by proximity to markets. Although labour cost and productivity create some basis for differentiation, these can be overcome through the introduction of low-cost computer-enhanced manufacturing equipment. As the opportunities for differentiation in price have diminished there is now more emphasis on product quality and order cycle. ${ }^{74}$

One key chain in this long list of logistics services involves international maritime transport. Historically, most industrialized countries used to own large national fleets, manned by national seafarers, built in national shipyards and flagged at home. ${ }^{75}$ Today, globalization has made shipping a highly competitive industry. Hence, a ship may be registered in one country, its owner from another country and its operator from a third country and the "components" of the shipping service, such as insurance, equipment, the work of seafarers, bunkering, ship repair or certificates of classification societies are very likely to have been purchased in a number of different countries. ${ }^{76}$ In the recent past, countries sought to increase their market share in the shipping industry in order to generate income. ${ }^{77}$ Today, for most developing countries, having access to

${ }^{71}$ Ibid.

72 UNCTAD (2003), Development Of Multimodal Transport And Logistics Services", Report by the UNCTAD secretariat, TD/B/COM.3/EM.20/2, p 3.

${ }^{73}$ John Arnold (2007), The Role of Trade Facilitation in Export Growth", (in) SADIQ AHMED and EJAZ GHANI (eds.), South Asia, Growth and Regional Integration, The World Bank, p 197.

${ }^{74}$ Ibid.

${ }^{75}$ UNCTAD (2003), "Efficient Transport And Trade Facilitation To Improve Participation By Developing Countries In International Trade" Note by the UNCTAD secretariat, TD/B/COM.3/60, p. 6.

${ }^{76}$ Ibid.

77 These attempts were supported by the United Nations through a number of initiatives, such as the adoption, under the auspices of UNCTAD, of the Convention on a Code of Conduct for Liner Conferences, 1974. 
adequate and inexpensive international transport services has become more important than generating income with the supply of such services.

In Ethiopia, problems in the maritime transport sector have become one of bottlenecks to international trade. The sector as will be seen below has fallen almost entirely into a state of state monopoly nearly without internal or external competition. This section attempts to demonstrate that the improvement in the performance of logistics services through domestic reform and international trade liberalization in Ethiopia may generate a virtuous cycle, whereby international trade is increased and that this, in turn, may increase the demand for logistics services. ${ }^{78}$ The benefits of improved performance of logistics services could be enhanced through governmental measures that assist the flow of trade across national borders. Further, trade facilitation measures instituted by the government, including but not limited to more efficient, well-coordinated border control mechanisms, may promote greater demand for logistics services. The extent and pace of measures taken by governments to liberalize the supply of logistics services and to facilitate trade will determine whether or not a virtuous cycle will be generated and the extent of the benefits that will accrue from that cycle. ${ }^{79}$

\subsection{Ethiopia's Maritime Transport Legislative and Institutional Framework: Restrictive Features}

There are essentially few factors that characterize the Ethiopian logistics and in particular maritime transport services environment in Ethiopia. First of all Ethiopia is a landlocked country. Ethiopian Shipping Lines and Logistics Enterprise (ESLSE) is a parastatal company owned by the state. It enjoys a monopoly in maritime transport and logistics services of the country. The Maritime Sector Administration Proclamation establishes the Maritime Affairs Authority, which has regulatory powers on maritime passenger transport. ${ }^{80}$ The Transport Authority, under the auspices of the Ministry of Transport and

${ }^{78}$ In a recent report prepared by the United States International Trade Commission (USITC) on the global market for logistics services, it was suggested that improving the performance of logistics services through liberalization may generate a virtuous cycle, whereby international trade is increased, which, in turn, increases the demand for logistics services., See U.S. International Trade Commission, (2005) Logistic Services: An Overview of the Global Market and Potential Effects of Removing Trade Impediments, Investigation No. 332-463.

${ }^{79}$ Institute for International Trade, University of Adelaide, supra note 69.

${ }^{80}$ Maritime Sector Administration Proclamation 549/2007, Federal Negarit Gazeta, September 2007. 
communications, is authorized to represent the Flag State. ${ }^{81}$ It is also responsible for the qualification, procedures, and technical standards for the supply of shipping services. The Ministry of Transport issues the competence certificate for Shipping and Forwarding Agents. ${ }^{82}$

Ethiopia's current level of investment regulation with respect to logistics services is highly restrictive. Among other maritime services, only forwarding and shipping agency services are expressly dealt with under Ethiopian laws. These services are reserved for Ethiopian nationals under the Investment Regulation No 270/2012. ${ }^{83}$ This is one of the only eight investment areas that are exclusively reserved for Ethiopians under the Regulation. Other than the above, customs clearing services is restricted to domestic investors.

Ethiopian Shipping and Logistics Services Enterprise (ESLSE) is the sole sea freight transport service provider in Ethiopia although there is no express reservation by law reserving this service to ESLSE. It is a state-owned company that has de facto monopoly on transport of import goods. On the other hand, it can be said that there is no restriction on sea passenger transport under Ethiopian laws. The service is not clearly addressed under the investment regulations and there is also no provider of such services presently. Yet it seems that this service sector is less practical as Ethiopia is a landlocked country and its current access to sea is done via Djibouti. Despite its similarity to goods, provision of such service is currently outweighed by the ease and cost advantages of air transport, and is probably going to remain dormant as it will bring its own challenges in transit negotiations with Djibouti. Similarly maintenance and repair and pushing and towing services are not mentioned in any of the laws. This may be owing to the fact that, as a landlocked country, these services are not provided within Ethiopian jurisdiction.

Other service areas in the sector include auxiliary services to all modes of transport, and that contains three specific service types, namely, cargo-handling, storage and warehouse, and freight transport agency services. As explained above, freight forwarding and shipping agency services are reserved for Ethiopian nationals under the investment regulation. On the other hand, the Freight Forwarding and Ship Agency regulation lists cargo handling and

${ }^{81}$ Pursuant to Proclamation No. 468/2005, Transport Proclamation, Federal Negarit Gazeta of The Federal Democratic Republic of Ethiopia, $11^{\text {th }}$ Year No.58, Addis Ababa- $6^{\text {th }}$ August, 2005.

82 As per the Regulations No. 37/1998, Council of Ministers Regulations No. 37/1998 Freight Forwarding and Ship Agency License Issuance Council of MinistersRegulations, Federal Negarit Gazeta of The Federal Democratic Republic of Ethiopia, 41h Year No. 46, Addis Ababa $-19^{\text {th }}$ June, 1998.

${ }^{83}$ Investment Incentives and Investment Areas Reserved for Domestic Investors Council of Ministers Regulation, Regulation No 270/2012. 
warehousing services as part of activities of freight forwarders. ${ }^{84}$ In doing so, Art 3(4\&5) list that warehousing and delivery services, and cargo handling equipment services are the functions of the freight forwarder. Thus, the Regulation governs freight forwarding services in all modes of transport, as it contains no references to specific modes of transport it applies to. This means that cargo handling and storage and warehouse services are reserved for Ethiopian nationals. Essentially the service is highly capital intensive industry and the significance of investment liberalization in the area should be discussed. Moreover, as one major area of discussion in Ethiopia's accession bid to join the WTO, and as evidenced from the various inquires submitted by WTO members, the issue of accession commitments in GATS will have to be considered.

\subsection{Multimodal Transport}

In 2007, the House of Peoples Representatives came up with the Multimodal Transport Proclamation, first of its kind in Ethiopia, which is issued with the intention of providing a legal framework regulating duties and liabilities of parties to a multimodal transport contract. ${ }^{85} \mathrm{~A}$ multimodal arrangement is a scheme whereby the transportation of goods is under a single contract but performed with two or more different means of transportation. The transporter is accountable for the entire journey, including the shipment's delivery at the final destination. ${ }^{86}$ The Proclamation defines international multimodal transport as; "the carriage of goods by at least two different modes of transport on the basis of a multimodal transport contract from a place at which the goods are taken in charge by the multimodal transport operator to a place designated for delivery. The operations of pick-up and delivery or goods carried out in the performance of a unimodal transport contract, as defined in such contract, shall not be considered as multimodal transport." 87

The Proclamation envisages that international transport of goods in Ethiopia is now to be carried out on a door-to-door basis under one contract and with one party bearing contractual responsibility. Accordingly the proclamation introduces what is called "Multimodal Transport Document" which is a document that evidences a multimodal transport contract, the taking in charge of the goods by the multimodal transport operator, and an undertaking by him to

${ }_{85}^{84}$ Freight Forwarding and Ship Agency License Regulation, Reg No. 37-1998.

${ }^{85}$ Multimodal - Transport of Goods Proclamation; Proclamation No. 548/2007, Federal Negarit Gazeta of the Federal Democratic Republic of Ethiopia, $13^{\text {th }}$ Year, No. 59, Addis Ababa, 04 September 2007.

${ }^{86}$ According to the government the multimodal service is aimed at streamlining shipments from Port of Djibouti to avoid warehouse fees in foreign currency.

${ }^{87}$ Multimodal - Transport of Goods Proclamation, Art 2(1). 
deliver the goods in accordance with the terms of that contract. ${ }^{88}$ In doing so, the scope of application of the proclamation is overarched to all multimodal transport contract after the conclusion of which a multimodal transport document is issued according to the relevant provisions of the Proclamation. ${ }^{89}$

Accordingly, the multimodal transport document is to be regarded as document of title. Thus, where every consignee named in the negotiable or nonnegotiable multimodal transport document and every endorsee of such document as the case may be, to whom the property in the goods mentioned therein shall pass, upon or by each reason of such consignment or endorsement shall have all the rights and liabilities of the consignor. ${ }^{90}$ The Proclamation further regulates liability for loss, damage or delay arising from multimodal transport. On final note however, the Proclamation does not regulate specific issues in multimodal transport administration such as licensing and supervision of the services providers. These issues were set to be dealt with under a more technical regulation that would be issued by the Council of Ministers. Unfortunately, despite various pronouncements from the Maritime Affairs Authority (MAA) on draft multimodal regulation, the Proclamation as it stands can hardly be put to use.

\subsection{Directives on Multimodal Transport}

Despite the lag in introducing a Multimodal Transport Regulation from the Maritime Affairs Authority, the Ministry of Transport (MoT), which has been encouraging the usage of a multimodal transportation system since 2007, and has issued a Multimodal Transport Implementation Directive, effective January 2012. ${ }^{91}$ The new directive mandated that goods being shipped through the Ethiopian Shipping and Logistics Services Enterprise (ESLSE) use a multimodal (land, sea, or road) transportation service operated solely by stateowned ESLSE. As indicated above, the multimodal arrangement is a system whereby the transportation of goods is under a single contract but performed with two different means of transportation. The carrier is liable for the entire journey, including the shipment's delivery at the final destination. The transportation can be performed by rail, sea, and road.

Among others, the Directive instructs all vehicles of three tonnes or less to be under the new scheme. The directive also underlines that all shipments that use

${ }^{88}$ Id, Art 2(4).

${ }^{89} \mathrm{Id}, \operatorname{Art} 3(1)$.

${ }^{90} \mathrm{Id}$, Art 7 (1).

${ }^{91}$ It is to be noted here that neither the content nor character of this instrument is officially and clearly indicated from the side of the Government. It appears now that there is still confusion on the status of the instrument between being a Directive or a Circular. 
multimodal transport deliver their cargoes to dry ports or warehouses that are authorized by the Ethiopian Revenue and Customs Authority (ERCA). All private importers, that open Letter of Credit (LC) from local banks, are required to bring their container shipments to dry ports and ERCA's warehouses. ${ }^{92}$ The Directive is said to be aimed at streamlining shipments from Djibouti Port to avoid warehouse fees in foreign currency. It also stipulates for the confiscation of imported goods after shipments lie at the port for more than six months. Officials state that these schemes will save foreign currency for the country, which totals 1.4 million dollars, annually incurred as warehouse fees at Djibouti Port.

The first directive, effective as of January, does not require private importers to use the multimodal scheme even if they use ESLSE's service. The circular issued on February 13, 2012 required not only state banks but also private banks to undertake their activity under the new directive right away. The letter from the National Bank of Ethiopia also indicated that all banks have to report logistical data of their customers to the Maritime Affairs Authority and the National Bank of Ethiopia within the first five days of the month. ${ }^{93}$

As the Directive did not see other options until the directive allows private companies to be involved in the multimodal transport scheme, various interested groups are now arguing that the government must provide options for the private firms to compete in the sector. ${ }^{94}$ Those engaged in private forwarding business for instance argue that the government should undertake reform in this regard, inter alia, allowing freight forwarders and shipping agents to use other ships for cargo that transport from ports or countries that ESLSE's vessels do not call. ${ }^{95}$

${ }^{92}$ It is interesting to not here that there are complaints against the legislative power of the Ministry. Freight forwarders said that the ministry does not have the power to amend these types of enforcements on state or private banks as private multimodal operators are allowed to be involved in the industry.

${ }^{93}$ Addis Fortune, Supra note 50, The directive did not talk about any monopoly concerning the multimodal transport operation and because of that the ministry office should wait until private operators can be included in the sector before it amends enforcement regulations on banks."

${ }^{94}$ Interview with Commander Tilahun, Manager, Ethiopian Freight Forwarding and Shipping Agents Association.

95 According to a study by Addis Ababa Chamber of Commerce and Sectoral Association, waiver certificate allowing the sea voyage to be made by another carrier must be obtained by the importer, at a cost of USD 600-800 per container. See Private Sector Development Hub,(2009), The Management of Commercial Road Transport in Ethiopia, Addis Ababa Chamber of Commerce and Sectoral Associations, p. 159. 


\subsection{Ethiopian Shipping and Logistics Services Enterprise (ESLSE), Monopoly, Implications and Effects}

Before ESLSE was established upon the amalgamation of three enterprises including Ethiopian Shipping Lines, the National Bank of Ethiopia has already issued, in 2008, a directive requiring importers to use Ethiopian Shipping Lines as a requirement for Letters of Credit (L/C). In cases where ESLSE vessels do not call on ports from which goods are shipped and ESLSE does not have a slot charter relationship with carriers calling on these ports, it provides waivers to importers to use other carriers. Since almost all commercial imports in Ethiopia require L/C to obtain foreign currency, ESLSE enjoyed an effective monopoly on most imports into Ethiopia excluding non-commercial imports.

It is thus the collective effect of the above directives that has granted de facto monopoly to ESLSE. This measure has turned what used to be a struggling enterprise in the country to one of the most profitable state companies. However, this has now resulted into corporate inefficiency and increase in prices for services rendered by ESLSE. Recent reports disclose that, for instance, importers that used to import minibuses from Europe, in particular the Netherlands, have claimed to have paid 1,492 dollars to ship one vehicle which is $75 \%$ more than they used to pay before the de facto monopoly was established by the introduction of the recent directives. ${ }^{96}$ Importers claimed that the directive has taken away the opportunity of negotiations on shipment prices, since it is monopolized by the ESLSE. Importers have disclosed that they used to pay on average price not more than 900 dollars for each minibus after negotiations with many shippers. The same opinion is stated by Mulugeta Assefa, former president of the Ethiopian Freight Forwarders \& Shipping Agents Association (EFFSAA). ${ }^{97}$

ESLSE rates in 2008 were about 70 per cent higher than the Far Eastern rates. Sea freight cost covers about 60 percent of the total import supply chain costs to Addis Ababa. ${ }^{98}$ Considering the economic impact of the above finding, the impact on processing and manufacturing industries is easily noticeable. Apparently, many components and intermediates in the production of exported goods in Ethiopia need to be imported from abroad. Most of these components are subject to a five to ten percent tariff that adds to production costs. Packaging

\footnotetext{
${ }^{96}$ Transport Ministry Makes Waves with Multimodal Directive", Addis Fortune, Volume 12, Number 608, Dec 25, (2011). $<$ http://addisfortune.com/Vol_12_No_608_Archive/Transport\%20Ministry\%20Make s\%20Waves\%20with\%20Multimodal\%20Directive.htm>

${ }^{97}$ Ibid.

${ }^{98}$ Nathan Associates (2009), Impact of WTO Accession on the Transport Services Sector of Ethiopia, Ministry of Trade and Industry, Draft Final Report, p IX.
} 
materials like glass bottles imported for food processing are examples in this regard. They are not produced domestically and those that could be imported via road transport from neighboring countries are of poor quality. The available suspension schemes and drawback mechanisms are unable to reduce such costs for exporters and should be reformed. Accordingly, shipping costs will be brought to the forefront in increasing the costs for the nascent manufacturing sector in the country. Consequently, studies have indicated that the preference for ESLSE under the foreign exchange directives may increase shipping costs by an estimated $30 \%-50 \% .{ }^{99}$ Currently ESLSE has also received very low mark for its punctuality. ${ }^{100}$

\subsection{Ethiopia's WTO Accession and GATS Service Commitments: Implication for Maritime Services Liberalization}

The General Agreement on Trade in Services GATS is an agreement that lays down a framework of international rules for trade in services. The main principles that apply to the GATS ${ }^{101}$ are market access and national treatment while the schedule of commitments provides the basic framework for the results of negotiations. In terms of market access, GATS does not provide positive and normative definition for market access but only provides six types of restrictions that a member cannot impose, unless identified in its schedule. ${ }^{102}$ Conceptually this is also similar to the principles of quantitative market access limitations under GATT Art XI. Generally, GATS Art XVI:2 provides for rules that prohibit members from imposing market access limitations. The existence of any limitation in respect of these areas has to be indicated with respect to each of the four modes of supply in scheduled sectors. ${ }^{103}$ The idea is that such market access limitations are prohibited even if they are not discriminatory. ${ }^{104}$

However, GATS does not provide a comparable list in respect of national treatment restrictions, and it is up to members to ensure that all potentially

${ }^{99} \mathrm{Ibid}$

100 Bemnet Aschenaki (2004), "Transport Costs in Ethiopia: An Impediment to Exports?", Background study for the World Bank FY04 Country Economic Memorandum for Ethiopia, p 9.

101 GATS, World Trade Organization (1999), The Legal Texts, The Results of The Uruguay Round Of Multilateral Trade Negotiations, Marrakesh Agreement Establishing The World Trade Organization.

${ }^{102}$ Id, Art XVI.

${ }^{103}$ WTO, (2001), Guidelines For The Scheduling Of Specific Commitments Under The General Agreement On Trade In Services (GATS), Adopted by the Council for Trade in Services.

${ }^{104}$ N Icolas F. Di Ebold, (2010) Non Discrimination In International Trade In Services 'Likeness' In WTO/GATS, Cambridge University Press, p. 29. 
relevant measures are listed in sectors where commitments are scheduled and, if they wish, members can inscribe various types of national treatment limitation (e.g., regarding taxation or regulations). ${ }^{105}$ "If a member no longer wishes to conform to its specific commitments, it may modify its schedule by providing compensation in the form of alternative market access (even across sectors)."106 "However, this undertaking may involve difficult negotiation and often creates confusion regarding the member's commitments."107

With respect to the final part of the GATS framework, the GATS schedules are key framework instruments providing the list of services with members' commitments in terms of market access, national treatment and additional commitments. The lists of services correspond to GATT secretariat classification, ${ }^{108}$ which is a standardised harmonized framework also following numerical references to the Central Product Classification system of the United Nations. $^{109}$

As explained above, the Ethiopian Shipping and Logistics Enterprise (ESLSE) enjoys monopoly advantages. It is, in effect, a price setter as no competitor can force it to lower its prices through competitive methods. This in turn means that the importer is forced to accept the price set by the shipper. ${ }^{110}$ This setting will become an issue for WTO members in Ethiopia's accession negotiation. It is the objective of this section to exemplify how the interplay between liberalization of logistical services on the one hand, and trade facilitation on the other hand, is equally complimentary and should be borne in mind in the context of WTO negotiations on services and trade facilitation. Thus, negotiators in both contexts should at least explicitly recognize the

${ }^{105}$ Art XVII, In particular Art XVII lit 2 states; A Member may meet the requirement of paragraph 1 by according to services and service suppliers of any other Member, either formally identical treatment or formally different treatment to that it accords to its own like services and service suppliers.

${ }^{106}$ International Monetary Fund, (2010) Reference Note on Trade in Financial Services, Prepared by the Strategy, Policy, and Review and Legal Departments, p. 5.

$<$ http://www.imf.org/external/np/pp/eng/2010/090310.pdf $>$ General Agreement on Trade in Services (GATS), Art XXI: Modification of Schedules.

${ }^{107}$ Ibid.

${ }^{108}$ See Uruguay Round, Services Sectoral Classification List, Note by the Secretariat, MTN.GNS/W/120 (10 July 1991).

109 Various versions available, see for instance, United Nations CPC classification (Statistical Papers, Series M, No.77, 1991) Central Product Classification, CPC Version 1.1, (Updated: 21.02.2002), Version submitted to the United Nations Statistical Commission, (5-8 March 2002).

110 Derk Bienen et al. (2005), Impact Assessment of WTO Accession, Technical Assistance to Support Ethiopia in its Accession to the WTO, p. 69. 
potential for mutual reinforcement of liberalization of the logistics sector together with trade facilitation. ${ }^{111}$

It is the position of this author that Ethiopia, as a least developing country have much to gain from the liberalization of logistics services. The benefits that may accrue to suppliers of logistics services, exporters and importers that are dependent upon such services and nations as a whole are clear. Logistics liberalization facilitates international trade, which, in turn, drives economic growth and development. Trade facilitation measures that promote trade may also consequently promote greater demand for logistic services, thereby generating a virtuous cycle. ${ }^{112}$ The following paragraphs further investigate the nature of GATS negotiations and possible implications for reform.

\subsubsection{National Treatment on Maritime Transport and related Logistics}

National treatment, if committed, can be the most important principle applicable to maritime transport. Under the GATS, parties shall accord to other Parties no less than that accorded to domestic services or domestic service providers. Equality of treatment between foreigners and nationals imply that protectionist measures, such as cargo reservation and preference for national shipping, discriminatory taxes and charges towards foreign flag ships etc., are contrary to this principle. ${ }^{113}$ The implementation of the National Treatment clause may bring about at least the following effects.

The first important effect of the implementation of National Treatment principle to shipping and the Maritime sector is related to the current cargo preference policy. One can anticipate that WTO members will seek at least a minimum of few commitments here. In doing so, the lifting of cargo preference policy will be an important step towards the integration of Ethiopian maritime sector to international shipping competition and the efficiency in multimodal transport.

In terms of the other investment regulations, only Ethiopian nationals are permitted to invest in shipping agency services. It is unclear whether this prohibition implies that non-resident shipping agents are barred from supplying services cross-border into Ethiopia - this would be Mode 1 in GATS terms. Also

${ }^{111}$ UNESCAP (2007), Trade Facilitation Beyond The Multilateral Trade Negotiations: Regional Practices, Customs Valuation And Other Emerging Issues, A study by the ${ }^{112}$ Ibid. Asia-Pacific Research and Training Network on Trade, 276.

${ }^{113}$ H.E. Haralambides (1994), GATT and its Effects on Shipping and Ports", Proceedings of the KMI/IAME Conference on International Trade Relations and World Shipping, Seoul (1994), p. 13.

$<$ http://www.maritimeeconomics.com/downloads/papers/HH_GATT\%20Seoul.pdf $>$ 
unclear is whether Ethiopians are barred from utilizing the services of foreign ships agents abroad. This is called consumption abroad or GATS Mode 2. In terms of national treatment provisions under GATS, it is clear that no investment license can be issued to a foreign company or national to invest in a shipping agency enterprise in Ethiopia. These restrictions will have to be kept in mind if Ethiopia decides to include these activities in its WTO accession commitments. "Given the international nature of the shipping agency business, Ethiopia should anticipate that other WTO members may seek market liberalization measures in this area". ${ }^{114}$

The implementation of National Treatment may also have its own implication in terms of multimodal transport services. As indicated in the sections above, Ethiopia has made some progress towards creating an enabling framework for integrated logistics services through the adoption of legislation on multimodal transport. However, restrictions on investment by foreigners in key areas such as shipping and the apparently confusing regulations relating to freight forwarding and shipping agency will effectively hinder foreign logistics providers from investing in multimodal services. It thus would be wise that the Ethiopian government reviews its investment policy with regard to all auxiliary transport services with a view towards liberalizing market access in this area. One thus could also anticipate that WTO members will seek express commitments from Ethiopia in this area. ${ }^{115}$ Commitment of such nature thus may generally mean the entitlement of foreign shipping service providers to access Ethiopia's economy, customs clearance, maritime agency, freight forwarding and so on. With respect to all these facilities or services, foreign ships would then be treated in the same way as domestic ones.

Another important implication of commitment in national treatment would relate to the ability of foreign companies to own and operate a dry port infrastructure and facilities. Perhaps national treatment commitment in this area would carry a key tool to liberalize multimodal transport. If commitment is undertaken, the investment could be facilitated for instance through leasing and rental arrangement with the government. This option also seems economically compelling from experience.

\subsubsection{Market Access}

Together with National Treatment, Market Access is the second most important clause for implementing the principle of non-discrimination. Market access implies that Members will grant treatment to services and service providers of

\footnotetext{
${ }^{114}$ Nathan Associates, supra note 98, p. 110.

115 Ibid.
} 
other Members no less favorable than that provided for under the terms of their Schedule. ${ }^{116}$

Upon Ethiopia's accession, two issues immediately arise with regard to market access: the establishment/commercial presence by foreign companies and the right to provide services. Regarding the establishment of commercial presence, the effect could differ considerably among different market strategies by foreign companies. Commercial presence could take various forms and could be in charge of different activities. These activities may be the marketing and sale of maritime transport services; the purchase and use of any transport and related services; transport documentation; customs and other activities; provision of business information and freight forwarding and agency services and related activities.

The other issue which can be of fierce debate between Ethiopian negotiators and WTO members will be on the issue of freight forwarding and shipping agency services. Experience now shows that there is a considerable level of commitment undertaken by other acceded countries. Policy wise, one can find some shallow rationale and standing by the government. For instance, if one investigates the rationales behind current level of investment restrictions in shipping agency services, it seems that it is a genuine concern of the Ethiopian government to encourage the growth of the domestic shipping agency industry. However, this provision would prevent, in the long run, a foreign multimodal transport operator (MTO) which includes shipping agencies within its service offering, from setting up an agency office in Ethiopia. In effect, the restriction would force the MTO to locate itself outside Ethiopia. Such development will represent an investment loss for Ethiopia. ${ }^{117}$ It thus seems logical for the Ethiopian government to amend the investment regulation to permit foreign investors to provide ship agency services in Ethiopia.

Inland transport can also be an objective of further liberalization. As international transport becomes more integrated, and considering the advantages of multimodal transport, many shipping companies, or their subsidiaries, are trying to start their business in inland transport, particularly in trucking. As a first step, the possibility of freely contracting with any local transport service providers might be granted to foreign shipping companies, especially those in liner shipping. This free choice of local transport suppliers will surely increase the competitiveness of the local transport market.

As indicated above, the provisions of National Treatment and Market Access are binding only in so far as Member's Schedules specify. If they are negotiated

${ }^{116}$ Haralambides, H. E., et al (1994), GATT and its Effects on Shipping and Ports, $<$ http://www.maritimeeconomics.com/downloads/papers/HH_GATT\%20Seoul.pdf >

${ }^{117}$ Nathan Associates, supra note 98, p IX. 
and become at least subject to minimal level of commitment, Ethiopian Maritime transport sector may see robust domestic competition, and increase its international competitiveness further promoting trade facilitation down the line. This objective could be promoted, at least in medium terms, without a commitment in market access if a standstill commitment which would prevent the introduction of new restrictive measures, within a given period of time, is acceptable as a compromise. During that time Ethiopian maritime transport sector (in particular the shipping industry) will have to strengthen itself and adjust in order to be able to compete with others under terms of free and fair competition.

\subsection{The Role of Maritime Transport Sector Liberalization for Trade Facilitation in Ethiopia}

Maritime services and related logistics are important to a large number of sectors in Ethiopia's economy because of their direct link to both exports and imports. Improving the efficiency of maritime transport and related logistics can have significant positive spillover effects on encouraging trade flows, private investments, and subsequently enhancing production and job creation in almost every sector of the economy; for instance by reducing costs of imports for producers and consumers, at the same time increasing government revenue.

The preceding discussion leads one to press the need for a general change in policy directions in the maritime transport sector in Ethiopia. Generally, the reliance on national shipping and maritime transport has proved an expensive venture. About $95 \%$ of Ethiopia's foreign trade by weight/volume and about $70 \%$ by value involve transportation by sea. Following liberalization and opening up of the economy in the early nineties, there has been a significant increase in Ethiopia's maritime trade. In this short time, considerable improvements of containerization of general cargo, carrying capacity, etc. have been brought about in the sector. Yet, there are still large gaps between what is needed and what is in existence.

Today, uncompetitive import and export terms have become emerging problems for Ethiopia's budding economy. ${ }^{118}$ As long as semi value added goods dominate the industrial exports of the nation, transport costs constitute a large portion of the total export value. While the sector seems to have been given less attention from policy makers and economic research, findings by the World Bank (WB) now puts the average share of transport at 28 per cent of the

${ }^{118}$ Addis Fortune, Logistics Malaise Regulate, Monopolize Not!, Addis Fortune, (March 04, 2012).

$<$ http://addisfortune.com/Vol_12_No_618_Archive/Logistics\%20Malaise\%20Regul ate\%20Monopolise \%20Not.htm > 
value added to Ethiopian goods. ${ }^{119}$ While it costs 0.07 dollar cents to transport a shirt from Bangkok, Thailand, to New York, the cost of transporting the same shirt from Addis Ababa to New York is 0.11 dollar cents. While it takes 27 days for a Thai exporter to send its goods to New York, studies show, it takes five more days for the Ethiopian exporter. ${ }^{120}$

The monopoly also has its own time constraints especially in areas where the ESLSE does not have routes and has yet to subcontract them. Under the current situation, all LC shipments must be handled by ESLSE. If that port is called by the ESLSE, then, it will be about ESLSE's capacity to pick it up. If ESLSE does not call that port, it has the slot system, agreements with other shipping lines to pick cargo up on its behalf at a premium price. ${ }^{121}$ This venture is entirely dependent on the contractual arrangement to be reached by ESLSE and its client. This often takes considerable time and causes delays. The evidence could even be staggering if one looks into what is going on in the ground. Local experts and stakeholders state that it often takes ESLSE from 15 days - upto two months, at least, to collect goods from various import destinations by its slot partners. ${ }^{122}$

Yet, even when the port is called by ESLSE, the number of vessels it has and the volume of cargo that needs to be transported are often incompatible. Local experts state that ESLSE's ships cannot efficiently serve the import of the country, be it on a slot basis or on their own. ${ }^{123}$ According to them, the problem starts at origin ports, where goods stay at the ports more than they have to; even if ESLSE picks them up, it may not pick them up on a timely basis. ESLSE could or should have outsourced the said services but rather chooses to handle the fright by its own ships while its ships are not available. In many cases its takes ESLSE ships to have round trips to the same port more than once to clear the goods waiting for shipment to Ethiopia. This entails costs not only for storage but for all programmes in Ethiopia waiting for the goods that face the delay. ${ }^{124}$

119 Ibid.

${ }^{120}$ Ibid.

${ }^{121}$ Ibid

${ }^{122}$ Commander Tilahun, President of Ethiopian Freight forwarders and Shipping Agents Association, Interview with the author, July 2012. This has high impact for trade and it is not difficult to calculate the economic implication of this delay. See Gael Raballand et al., (2012) Why Cargo Dwell Time Matters in Trade, World Bank Economic Premise, Number 81.

${ }^{123}$ Addis Fortune, supra note 118.

${ }^{124}$ Ibid, 
Hummels, estimates that each day saved in shipping time is equivalent to about $0.8 \%$ reduction an ad valorem tariff. ${ }^{125}$ For certain production processes which are recently booming in Ethiopia, such as in electronics, textile and apparel or other assembly-type operations (engines and motor vehicle), which require high import content and have small per unit profit margins, delay and high shipping costs can put investment in this areas out of picture. ${ }^{126}$ Further, as these costs have ultimately to be borne by the end users, and where these users are potential exporters in the domestic market, these factors inevitably raise the cost of Ethiopia's exports in international markets and the prices of imports for the Ethiopian economy. As a local transport economist notes:

for all practical reasons, we need the company to serve this country but not at the cost of the whole national economy. Compared to other lines serving Ethiopia from Europe, for example, using [ESLSE] has a $40 \%$ rise in price. For everything coming from India, the price increment is close to $30 \%$. From Dubai, it is $20 \%$. From China, it is close to $30 \%$. Should we carry this burden for the survival of ESLSE? Or should we let it go free and have them work on competitive basis? One of the major factors hindering the fair distribution of logistic costs in the economy is the monopoly issue. ${ }^{127}$

In terms of the need for the liberalization of the maritime transport sector in Ethiopia (and the role of WTO accession in this regard), this article brings into attention a classical political economy argument in favor of undertaking commitments for this service in the WTO. The WTO accession efforts could bring fertile opportunities where genuine economic reform needs would meet with multilateral economic negotiations. Primarily, commitments in the sector could provide legal guarantees and certainty to services providers (foreign and local) thereby introducing foreign competition or fostering existing foreign competition) in transport services. This consequently could bring more investment through legal certainty and irreversibility of conditions of operations, wider choice of services for the consumer including state of the art services, such as supply chain management for instance, lower prices of services through competition with national incumbents and other foreign providers, and effective technology transfer through the use of modern equipment and management methods and through the employment and training of local staff which will then,

${ }^{125}$ David Hummels, (2001) Time as a trade barrier" Purdue University, p 3.

${ }^{126}$ See Liliana Annovazzi-Jakab, (2003), Landlocked Countries: Opportunities, Challenges and Recommendations (in) Carol Cosgrove-Sacks and Mario Apostolov (eds.) Trade Facilitation; The Challenges for Growth and Development, United Nations Economic Commission for Europe, $\mathrm{p} 86$.

${ }^{127}$ Addis fortune, supra note 118. 
at least in the long run, will be able to create its own businesses at least in sub sectors with low costs of entry. ${ }^{128}$

Generally, experience over the last decade has shown that state-owned transport monopolies may not be the most efficient way to assist the trade of a country. Consequently, developing countries like Ethiopia should be encouraged to promote private transport companies, be they shipping companies, trucking companies or railways. It is argued that maritime and (road transport) monopolies often seal off developing economies from the natural growth of domestically based transport enterprises. ${ }^{129}$ In Ethiopia, while there are not sufficient level studies evidencing the this conclusion, there are reports from various industry groups which show that industries in Ethiopia suffer from the current state of maritime transport performance in the country. Industries report a very serious disadvantage for Ethiopian industries vis-à-vis those that reside in Asian economies with respect to inventories and input costs. On average, the reports indicate that Ethiopian industries hold twice as much raw material and finished products compared to their Asian counterparts. ${ }^{130}$ According to the reports, higher transaction costs explain a relevant part of the discrepancies in these inventories: Ethiopian industries faced with higher prices, uncertain demand and longer delays for small frequent shipments choose to maintain larger reserves. ${ }^{131}$ As business people comment with frustration,

there are certain ports wherein the [ESLSE] may not accept bulk cargo (i.e., un-containerized cargo). In order to containerize a cargo, the consignment needs to be at least 10,000 to 12,000 kilograms. For different reasons, bulkpurchasing is not widely practiced in Ethiopia, and the origins of imports are diverse. If a waiver is obtained from the [ESLSE], it is possible to nominate a foreign vessel for transporting such imports. But the mode of payment becomes C\&F, instead of FOB. Arranging for such a change in bills of lading takes a lot of time and becomes a source of delay. ${ }^{132}$

Considering that the cost of capital is excessively high in Ethiopia than in Asia, the rest of Africa and Latin America, the commentators point out that these high inventory levels translate into considerable costs, and ultimately in lower

${ }^{128}$ SADC "Advantages Of Gats Bindings For The Transport Sector" $<$ https://tis.sadc.int/files/3413/2644/9883/Advantages_of_GATS_Bindings_for_the Transport_Sector_2005_Latrille.pdf $>$

${ }^{129}$ Carlos F. de Castro, (1996) Trade and Transport Facilitation Review of Current Issues and Operational Experience, A Joint World Bank/UNCTAD Publication, SSATP Working Paper No 27.

${ }^{130}$ Tsegaye Teklu and Endris Negus, supra note 1, p 40.

${ }^{131}$ Ibid.

${ }^{132}$ Ibid. 
competitiveness and diminished growth. ${ }^{133}$ Considering liberalization of the maritime transport sector in the context of Ethiopia's WTO Accession, effort will thus be compelling and of high importance.

\section{The New WTO Trade Facilitation Agreement and Ethiopia: A Cross-Check}

While this article took a broad view to trade facilitation and analyzed issues such as logistics and customs valuation under this point of view, negotiations to reach agreement under a narrower perspective of the concept have already been under negotiation in the WTO since 2001 under Doha Development Agenda (DDA) negotiations. ${ }^{134}$ Despite the ultimate failure to reach agreement on compressive Doha agenda, WTO members were able to ink deal on a Trade Facilitation Agreement (TFA) in its latest Ministerial Conference in Bali, December 2013, as a part of a wider 'Bali Package'. ${ }^{135}$ At the time of this writing, the agreement still awaits ratification by at least two third of WTO members, to come into force. However a discussion on its potential implication for Ethiopia upon its accession to the system is necessary.

Generally the agreement covers provisions that aim to put discipline over various impediments to international trade such as cumbersome data and documentation requirements, disproportionate fees and charges, restrictive administrative regulations and excessive formalities and other border procedures. All of these are thought to impose unnecessary restriction on global

${ }^{133}$ Ibid.

${ }^{134}$ Initial steps started at the WTO Ministerial Conference in 1996 for examining how multilateral action by WTO Member governments might help to reduce these costs without interfering with legitimate border management objectives such as revenue collection and security. After some years of analysis and debate in the WTO, it was agreed in mid-2004 to address these obstacles by adding Trade Facilitation to the list of subjects that was being negotiated in the Doha Round. WTO Singapore Ministerial 1996: Ministerial Declaration WT/MIN(96)/DEC (1996); The Doha Work Programme Decision Adopted by the General Council on 1 August 2004 stated that - (Trade Facilitation) taking note of the work done on trade facilitation by the Council for Trade in Goods under the mandate in paragraph 27 of the Doha Ministerial Declaration and the work carried out under the auspices of the General Council both prior to the Fifth Ministerial Conference and after its conclusion, the General Council decides by explicit consensus to commence negotiations on the basis of the modalities set out in Annex D to this document. See World Trade Organization WT/L/579, 2 (August 2004).

${ }^{135}$ Bali Ministerial Declaration - WT/MIN(13)/DEC, Ministerial Conference Ninth Session Bali, 3-6 December 201; Agreement On Trade Facilitation - Ministerial Decision, WT/MIN(13)/36 - WT/L/911. 
trade. $^{136}$ The following paragraphs provide brief highlights to the principal substantive contents of the agreement in light of Ethiopia's practical context.

\subsection{Publication and Availability of Information}

The final text of the agreement calls upon WTO members to promptly publish all information on trade-related regulations and procedures of border agencies, applied rates of duties and taxes of any kind imposed on or in connection with importation or exportation, rules for the classification or valuation of products for customs purposes, regulations of general application relating to rules of origin and penalty provisions for breaches of import, export, or transit formalities and procedures for appellate review. This information should be available to all governments and traders in a non-discriminatory and convenient manner. The text of the agreement also lays down provisions on how WTO members should notify the WTO secretariat and others members including a specific provision on information that should be available through internet and provisions for the establishment of enquiry points to enhance the availability of trade-related information ${ }^{137}$ The current status of Ethiopia in this regard is at various stages of potential compliance with the provisions of the TFA.

\section{a) Publication of trade regulations:}

Ethiopia has a modest variety of official means used to notify, publish, and make available trade-related information; most official publications are in Amharic and English. Official Proclamations on trade-related issues - namely trade-related laws which are approved by Parliament, Regulations approved by the Council of Ministers are all published in the Official Gazette (Negarit Gazeta), which is printed by the state-owned printing office (Berhanina Selam). ${ }^{138}$ Occasionally, copies of these official documents run out and they can only be obtained from concerned government agencies. ${ }^{139}$

Directives that are approved by the Ministries, Agencies and various State Governments are not publicized in any formal way except in few cases where

${ }^{136}$ Richard Eglin, "The Doha Round Negotiations on Trade Facilitation", (in) World Economic Forum (eds.) The Global Enabling Trade Report- 2008 (2008), p 35.

${ }^{137}$ Agreement On Trade Facilitation, WT/L/931, Article 1.

${ }^{138}$ It is to be noted here that the newly enacted Mass Media and Access to Information law requires each state body to publish - its directives, regulations, guidelines. Federal Negarit Gazeta, 14th Year No 64, Freedom of the Mass Media and Access to Information Proclamation No 590/2008, Addis Ababa, 4th December, 2008. Article 13(1)(g).

${ }^{139}$ Generally see Mulugeta Getu, "Law Schools' Access to Legislation and Decisions: Current Trends and Suggested Outlets", Ethiopian Journal of Legal Education, Vol. 3, No.2 (December 2010). 
the relevant agency maintains websites. Other than these circulars and guidelines issued by government agencies on administrative, procedures are printed as hard copies by the relevant institutions or departments. In terms of customs laws, the ERCA publishes a general tariff book with preferential tariff rates and taxes, relevant laws, regulations, and procedures on its websites, in addition to publishing such information through the Gazette.

\section{b) Enquiry points/single national focal information centre:}

On general customs issues, the ERCA has a consultation department that provides information on customs issues relating to importation and exportation in Addis Ababa. The other border agencies do not seem to have similar structures or designated information desks like Customs. Generally, Ethiopia's border agencies would therefore need to establish inquiry points/desks or collectively establish a central enquiry point to meet the specific proposals for WTO Members.

\section{c) Notification of trade regulations:}

While Ethiopia has a mechanism for notifying the general public when amending and introducing new measures, the Trade Facilitation Agreement demands that such amendments - especially the ones that relate to core measures that may have significant effects on trade with other Members, interested parties, and the WTO Secretariat - should be notified to enable such parties to submit comments before the amendment is finalized. This notification might have to be similar to what is provided for under Technical Barriers to Trade (TBT) and Sanitary and Phytosanitary (SPS) Agreements.

As far as the notification provisions of the TBT and the SPS agreements are concerned, to date, Ethiopia has only made preparations to establish national inquiry point under the TBT agreement. ${ }^{140}$ Much work remains for Ethiopia to meet the rest of the notification requirements under the SPS agreement and the national notification authority. Notification obligations on the lines of the SPS Agreement and the TBT agreements will create additional pressure, even though this would be beneficial in adding transparency to the trading system. In some cases, the Ethiopian government has been given contributions from relevant stakeholders when establishing the inquiry point.

One of the challenges for Ethiopia will be the ability to make information available electronically and in a sustainable manner given limited connectivity, electric power interruptions and the limited availability of skilled manpower in information technology, at least in relevant government agencies. Most governmental agencies do not have official websites on which to publish

\footnotetext{
${ }^{140}$ See Ethiopian Standards Agency, WTO TBT Enquiry Point, $<$ http://www.ethiostandards.org/ESA/Contacts.aspx $>$
} 
information, and those that do only publish partial information which, in many cases, is outdated.

\subsection{Opportunity to comment, information before entry into force and consultations}

Article 2 of the Agreement contains provisions aimed at ensuring that there is a fair level of specified interval between publication and entry into force of laws and regulations applicable to international trade and consultations with stakeholders. ${ }^{141}$

Currently, in Ethiopia, time periods between publication and implementation varies from immediate to 4 days, 10 to 30 days, and 60 to 90 days. Information on when a Proclamation or Regulation would take effect is announced in the Official Gazette. The Customs Proclamation specifies immediate implementation while other instruments provide for some interim period of days between publication and implementation. Thus, the different time periods between publication and implementation present a potential problem for Ethiopia. Comparing the current situation with the relevant provisions of the Trade Facilitation Agreement for an agreed specific interval, Ethiopia would have to do away with the immediate enforcement provision, which does not provide for any time period between publication and implementation.

Moreover, Ethiopia does not have a well established mechanism for effective consultations. Very recently however, changes have been introduced with the support of International Financial Corporation (IFC). The Ethiopian Chamber of Commerce and Sectoral Associations has established The Ethiopian Public Private Consultative Forum (EPPCF). ${ }^{142}$ Consultations on various customs related issues have taken place prior to the introduction of new laws, giving stakeholders an opportunity to contribute to, influence, and comment on proposed changes to either existing or new laws and regulations before entry into force. Both informal and formal meetings and workshops facilitate consultation with relevant stakeholders. Invitations to such events normally state the policy objectives sought by a new law or an amendment, and the stakeholders are normally informed of deadlines for submission of comments. Almost all of the authoritative laws (Proclamations or Regulations) however

${ }^{141}$ ARTICLE 2: Opportunity To Comment, Information Before Entry Into Force, And Consultations, 1 Opportunity to Comment and Information before Entry into Force 1.1 Each Member shall, to the extent practicable and in a manner consistent with its domestic law and legal system, provide opportunities and an appropriate time period to traders and other interested parties to comment on the proposed introduction or amendment of laws and regulations of general application related to the movement, release, and clearance of goods, including goods in transit.

${ }^{142}$ See EPPCF website, <http://www.eppcf.com/?view=featured $>$ 
provide for consultations with the private sector when there is a need to change procedures.

Another issue of contention with some stakeholders is that these consultations are not encompassing enough and that in some cases the stakeholders lack technical capacity and information to engage effectively with the government on the issues under consultation. Generally, most of the institutions stated that there are no consultative mechanisms to provide an opportunity for stakeholders to comment before any new laws or regulations are introduced or before changes are made.

\subsection{Advance ruling}

Article 3 of the TFA contains provisions on advance rulings by WTO members. Generally the concept is defined as measures "designating the option for customs to issue a decision, at the request of the economic operator planning a foreign trade operation, relating to the regulation in force. The main benefit for the holder is the legal guarantee the decision will be applied."143 The TFA provides a mandatory rule that "each Member shall issue an advance ruling in a reasonable, time-bound manner to the applicant that has submitted a written request containing all necessary information."144

Currently, there is no applicable legal rule or procedure that allows advance rulings in any of the international trade administration agencies. However, a draft to Ethiopia's New Draft Customs Proclamation, includes some provisions on advance rulings. These include provisions for advance rulings on tariff classification, applicable duties and taxes, and valuation based on currently applicable valuation norms which apparently are not in line with relevant WTO rules. According to Article 95(1) of the Draft titled 'Advance Rulings': "The importer or his agent may be allowed, at request, to calculate the duty and taxes based on the information provided by the Authority before the goods enter the customs territory". Even if the Draft embodies such a provision, Ethiopia has a long way to go until necessary regulations/directives are introduced which would put the provision to use.

As far as tariff classification is concerned, Ethiopia has implemented the international 8-digit HS code tariff nomenclature; it is also a member to the WCO HS Convention ("The International Convention on the Harmonized Commodity Description and Coding System"). Application of this rule might on the other hand require that Customs officials should be provided with targeted training on implementing and operating advance rulings. Ethiopia may need to develop a database for advance rulings given that it imports almost all of its

${ }^{143}$ See provisions of standard 9.9 of the Revised Kyoto Convention that define the term.

${ }^{144}$ See TFA Article 3. 
industrial goods. The Draft has also considered providing for submission of a request for advance ruling through clearing agents. This provision would entail training clearing agents on how to determine value using transaction value, manage Advance Rulings, and maintain a database on Advance Rulings linked to the Customs database for Advance Rulings.

\subsection{Procedures for Appeal or Review}

The TFA contains rules that mandates WTO Members to provide any person the right to have access to 'an administrative appeal to or review by an administrative authority higher than or independent of the official or office that issued the decision; and/or a judicial appeal or review of the decision. ${ }^{145}$ In Ethiopia, according to applicable rules, right of appeal for imports, exports, and transit goods is a nondiscriminatory legal right against the rulings and decisions of Customs and other border agencies. Moreover, companies or traders have a right to be represented at all stages of appeal procedures by an agent or legal representative.

Provisions for traders to raise complaints concerning administrative decisions informally before moving to a formal appeal procedure exist. Yet the procedure seems to be lengthy and ineffective. Most businesses opt to pay rather than appeal in order to avoid incurring additional cost or possibly because the appeal procedures are too onerous. Although considerable steps have been taken to improve the Appeal system, a lot more still needs to be done. Accordingly, Ethiopia may need both human resources and time to introduce necessary changes to ensure compliance should the proposals be incorporated in the Trade Facilitation Agreement under negotiation. In addition, Ethiopia will have to ensure that, with respect to determinations of particular customs values, there is a truly independent administrative review coupled with similarly independent judicial review.

\subsection{Release and Clearance of goods}

Another important set of proposals in the WTO concerns the release and clearance of goods. ${ }^{146}$ The TFA requires Members to maintain pre-arrival processing and special procedures for express shipments. ${ }^{147}$ This means

\footnotetext{
145 Ibid, Article 4.

${ }^{146}$ TFA Article 7: 1 Pre-arrival Processing, 1.1 Each Member shall adopt or maintain procedures allowing for the submission of import documentation and other required information, including manifests, in order to begin processing prior to the arrival of goods with a view to expediting the release of goods upon arrival., 1.2 Each Member shall, as appropriate, provide for advance lodging of documents in electronic format for pre-arrival processing of such documents.

${ }^{147}$ Ibid.
} 
application and implementation of the provision would practically require PostClearance Audit by the relevant customs agencies.

Article 26(1) of Ethiopia's Draft Customs Proclamation allows pre-arrival clearance, and it provides: "The importer or his agent may lodge his declaration with supporting documents prior to the arrival of the goods and may request for a pre-arrival clearance to be issued upon examination of the declaration and supporting documents". Yet this statement in the draft is too generally and needs to be defined clearly in the implementing regulations. For express shipments, Ethiopia should enact and implement the principles contained in the WCO (World Customs Organization) Guidelines for the Immediate Release of Consignments by Customs. The Draft has also attempted to establish a formal system of creating authorized dealers who automatically qualify for accelerated clearance.

\subsection{Border Agency Coordination and Single Window}

Article 8 of the TFA Agreement requires WTO members to ensure that their 'authorities and agencies responsible for border controls and procedures dealing with the importation, exportation, and transit of goods cooperate with one another and coordinate their activities in order to facilitate trade.' To the extent possible it, inter alia, requires WTO members to establish a mechanism of one stop border post control.

Ethiopia currently meets some conditions specified in the text of the proposal but falls short on many others. As the current proposal is articulated with several enfeebling conditions ("endeavor," "encourage"), Ethiopia would be considered compliant insofar as its intentions are concerned. The reality on the ground however is more complex. There are some irregular meetings coordinated by Customs with various border agencies. Although Customs, Ministry of Finance and Ministry of Trade cooperate effectively, cooperation between other agencies is not really standardized. The situation is reflective of the overall dispersion of authorities in the area of international trade, where six ministries contribute without adequate coordination - to the formulation of trade policy and where more than ten statutory bodies can be involved in the importation and exportation processes of the trade facilitation.

As the primary entity responsible for the importation and exportation of goods, ERCA is often held accountable for delays or data issues that lie outside its control. Yet ERCA itself it not progressing with the apt speed and vigor that the nation currently needs. There is also no efficient electronic exchange of information between the ERCA offices in Addis Ababa and the satellite offices at border posts and other regional stations. Ethiopia does not also have a single window for customs facilitation purposes. It thus might need to work further in this regard if it plans to fulfill what could become a WTO trade facilitation agreement. 
Generally, while its progress is notable, Ethiopia nonetheless has much work ahead to bring its overall trade facilitation standards in line with the proposals that are under discussion in the WTO. And, it is only partially prepared to abide by the new set of rules under draft by the WTO Negotiating Group. The observations in the preceding paragraphs have shown both achievements and deficiencies and have noted where high level of early preparation may be advisable for bringing about the changes envisioned.

\section{Conclusion}

As the preceding section indicate the need for trade policy and other endogenous reform needs, in the area of trade facilitation. I generally argue that efforts toward streamlining economic development, trade and investment policy in Ethiopia with domestic legal and institutional reforms to facilitate trade are the very factors that render the country's pursuit of WTO accession and trade liberalization fruitful. In today's international business environment of global production network and just in time delivery, businesses seek cost-effective, efficient, and predictable facilitation in international trade.

As highlighted in this article, Ethiopia's customs administration is the foremost agency at the border and plays a prominent role in the release of goods. The implications of WTO membership include the development of traderelated institutions such as the laws and regulatory frameworks that govern trade as well as the administrative mechanisms and processes for designing, implementing and evaluating trade and trade-facilitation related policies. ${ }^{148}$ One instance in this regard relates to the discussion made with respect to the legal regime on customs valuation of goods in Ethiopia. The current practice of customs valuation in Ethiopia demonstrates that the WTO valuation methods are not fully incorporated in legislative guideline. As they cannot be applied effectively until necessary legislation is prepared and passed, the first key reform measure should involve legislative upkeep. Thus, legal inadequacy in Ethiopia still remains. What is needed is a comprehensive customs regulation with detailed definition of valuation terms, transparent provision of price adjustment, clear guidance to valuation and other similar measures. We can thus expect that customs reform and trade facilitation in Ethiopia will be driven by the Ethiopian government's decision to accelerate its WTO accession application.

\footnotetext{
${ }^{148}$ Lesser, C. and E. Moisé-Leeman, (2009) "Informal Cross- Border Trade and Trade Facilitation Reform in Sub- Saharan Africa", OECD Trade Policy Working Papers, No 86, OECD Publishing

$<$ http://dx.doi.org/10.1787/225770164564> (Last accessed April 2014)
} 
Meanwhile, the international movement of goods involves not only the customs administration but also other national economic activities and actors in the area of logistics and transport and national policies, regulations and authorities in the area of transport, health, agriculture, standards and other border agencies. Competition in the maritime transport sector in Ethiopia is indeed crucial for trade facilitation. However, Ethiopia has one of the most restrictive logistics regimes with a complete dominance of the state monopoly with almost no private competition. This has exacerbated other international trade barriers such as access to ports and location. The burden of high maritime transport cost is becoming one of the obstacles for industries in the country to function in a manner that is tuned into modern just in time international trade practice of the $21^{\text {st }}$ century. Therefore, as highlighted in the preceding sections, the benefits of improved performance of transport and logistics services could be enhanced through governmental trade reform measures. Trade facilitation measures, including but not limited to more efficient, well-coordinated border control mechanisms, may promote greater demand for logistics services.

Indeed, the extent and pace of measures taken by governments to liberalize the supply of transport and logistics services and to facilitate trade will determine whether or not a virtuous cycle will be generated and the extent of the benefits that will accrue from that cycle. ${ }^{149}$ This envisages a regulatory framework which can balance other domestic industrial policy with the need to foster the liberalization of logistics services. ${ }^{150}$ Frequent consultation with all the relevant stakeholders - governmental bodies, suppliers of transport and logistics services, and exporters and importers dependent upon international transport and in particular maritime transport and logistics services - will help to realize the benefits of economic and policy reform in the area. With a clear understanding of such ground-level needs, the government can use Ethiopia's currently ongoing negotiation efforts to WTO accession as a tool of institutionalizing its reform objectives.

${ }^{149}$ Institute for International Trade, University of Adelaide, supra note 69.

${ }^{150}$ Ibid. 